\title{
Literature review and comparative analysis of inland waterways transport: “Container on Barge”
}

\author{
Fan $\mathrm{Bu}^{1} \cdot$ Heather Nachtmann ${ }^{1}$
}

Accepted: 17 June 2021 / Published online: 26 July 2021

(c) The Author(s) 2021

\begin{abstract}
Container on Barge (COB) facilitates intermodal transportation by transporting shipping containers on barge tows. $\mathrm{COB}$ has seen rapid expansion globally over the past 20 years, providing a cost-efficient, environmentally friendly, and congestion-reducing mode of container transportation. European countries have led COB transportation in both study and application over the past two decades. However, increasing interest is observed in both the USA and Asia. In this literature review and comparative analysis, 135 COB-focused peer-reviewed articles are reviewed and analyzed to systematically describe the development and current status of COB transportation research. The relevant literature is analyzed to reveal publication rates and titles, geographical regions of interest, research questions, applied methodologies, advantages of COB transportation, and key success factors. The aim of our effort is to provide information on various aspects of COB development among different regions in the world and to summarize the existing literature to support and guide future $\mathrm{COB}$ development.
\end{abstract}

Keywords Container on barge $\cdot$ Inland waterways transport (IWT) $\cdot$ Maritime transportation $\cdot$ Intermodal transportation $\cdot$ Literature review $\cdot$ Comparative analysis

\section{Introduction}

With the increasing growth in the global container shipping market, the inland waterways transport (IWT) of containers is garnering increasing interest as a reliable and low-cost alternative mode to roadway transportation (Konings 2007; Caris et al. 2011). Container on Barge (COB) transports containers between river ports and seaports via barge tows along accessible inland waterways (Shobayo and van Hassel 2019). Beginning in the 1990s, COB started to develop in

Heather Nachtmann

hln@uark.edu

1 College of Engineering, University of Arkansas, 4207 Bell Engineering Center, Fayetteville, AR 72701, USA 
Northwestern Europe (Netherlands, France, Germany, and Belgium). With the supportive regional government policies, COB transportation embraced a significant market growth, making a breakthrough to three million twenty-foot equivalent units (TEUs) by the end of 2000, three times the TEUs in 1990 (Konings and Priemus 2008). After 2000, with the enabling political arrangements of the container transportation channel between the seaports (Shanghai, Shenzhen, and other southern seaports) in China and European seaports, COB expanded well into the Serbia, Slovakia, Austria, and Poland where IWT shows strong connectivity with seaports (Grobarcikova and Sosedova 2016). In the last decade, China and the USA appear to be catching up, with interest in the development of COB transportation (Konings 2006; Notteboom et al. 2020).

Based on the existing literature, there are three widely accepted benefits of COB that make its development worthwhile. First, transporting containers by barge can significantly reduce shipping costs because of the high fuel efficiency of IWT (per ton per mile) compared with truck or rail transportation. According to the Oklahoma Department of Transportation (2019), on average, one gallon of fuel can move a ton of cargo 576 miles by barge, 413 miles by train, and only 155 miles by truck. The infrastructure cost for barge transportation is 12.6 EUR per thousand ton-kilometers, while it is 45.21 EUR for train and 48.42 for truck, indicating that barge transportation infrastructure cost is about four times less than train or truck (Gharehgozli and Zaerpour 2018). Second, COB is more environmentally friendly compared with other transportation modes. For example, the environmental cost for transporting containers by barge is 0.27 cents per ton per kilometer, while it is 2.01 cents by train and 0.80 cents by truck (Gharehgozli and Zaerpour 2018). Third, COB transportation can alleviate port congestion. According to a study conducted by Zweers et al. (2019), 40\% of trucks in the Port of Rotterdam experience heavy delays, and the development of COB could enable the port to switch container transport from truck to barge, thus making the port area more accessible.

From our inquiry, it appears that this article is the first to present a comprehensive literature review and comparative analysis of $\mathrm{COB}$ research. The aim of our work is to describe the current status of $\mathrm{COB}$ research, summarize information related to key aspects of $\mathrm{COB}$ research among different regions in the world, and provide a literature database for future $\mathrm{COB}$ research and development. The article examines the similarities and differences of existing COB studies and classifies each reviewed article to enable future researchers to efficiently locate COB transportation information of interest.

A systematic search of the peer-reviewed literature related to Container on Barge (COB) was conducted. Nine keywords were identified: "container," "barge," "inland waterways," "IWT," "river transportation," "inland terminal," "Yangtze transportation," "Mississippi transportation," and "multimodal transportation." We used two search strategies: (1) search for keywords "container" and "barge" simultaneously and (2) individually search keyword combinations by combining each of the other eight keywords with the keyword "container." Using these search strategies, we identified 285 articles published from January 2000 to April 2021 from the following six databases: Compendex, TRID, Business Source Complete, ABI/INFORM Collection, INSPEC, and Web of Science. After 
reviewing the content of these articles, 135 of them were retained for inclusion in our analysis, judging from their focus and high relevance to COB.

Our findings are organized in the seven sections that follow: (1) Annual publication count of COB articles, (2) Journals publishing COB research, (3) Geographic region of $\mathrm{COB}$ research, (4) Research questions studied in COB literature, (5) Methodological approaches employed in COB research, (6) Advantages of $\mathrm{COB}$, and (7) $\mathrm{COB}$ success factors. Each section describes a key aspect found to be important in describing and understanding the COB literature. In each section, the selected $135 \mathrm{COB}$ articles are further classified to provide detail into each key aspect of COB.

\section{Annual publication count of COB articles}

In this section, the selected 135 Container on Barge articles are counted per year to compute the annual publication count (the number of articles published per year). Figure 1 shows the number of $\mathrm{COB}$ articles published each year from January 2000 to April 2021. The annual publication count fluctuates between zero and 3 from 2000 to 2010 before it begins to increase gradually until reaching the peak in 2020 with 19 articles published. Four COB articles were published in the first 4 months of 2021.

Comparing the past decade with the one prior, the average annual publication count of $\mathrm{COB}$ articles has more than doubled. The year in the past decade with the lowest COB publication count (2012) has five COB publications, which is greater than that of any year between 2000 to 2010. Another observed trend is the rapid growth in annual publication count observed between 2011 and 2020, as shown in Fig. 1. These observations indicate that research on COB is receiving increasing attention from scholars.

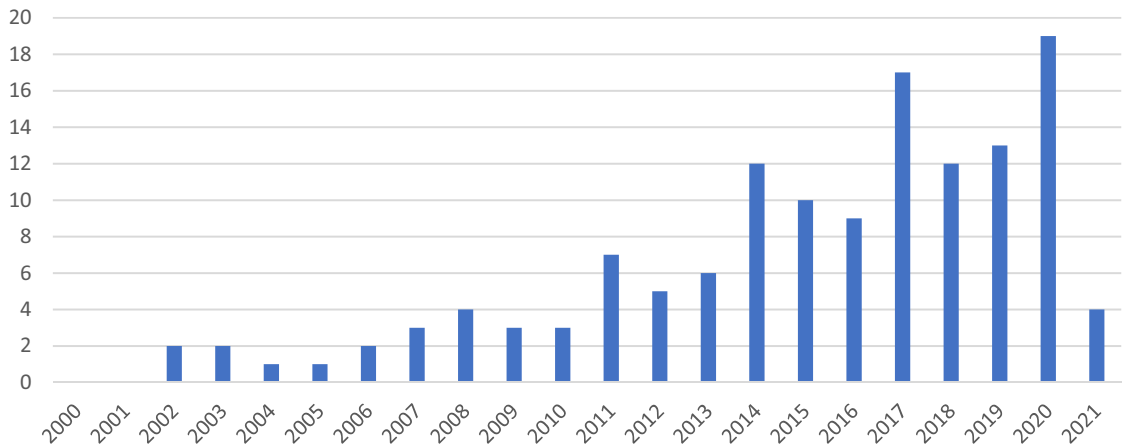

Fig. 1 COB articles published annually from January 2000 to April 2021 


\section{Journals publishing COB research}

The journals that published the selected 135 COB articles between January 2000 and April 2021 are reported in this section. As presented in Table 1, the Journal of Transport Geography ranks in the top position with ten COB publications. This is closely followed by European Journal of Operational Research and Transportation Research Part E: Logistics and Transportation Review, each with nine COB publications, Transportation Research Record with eight COB publications, and Maritime Economics \& Logistics with seven COB publications.

In general, the journals publishing $\mathrm{COB}$ research indicate a wide range of application areas. There are more than 60 journals across a wide variety of topical research areas that have published at least one COB article between January 2000 and April 2021. This indicates that COB is being studied not only by scholars in the transportation area but also in other areas, e.g., computer science, economics, and civil engineering.

\section{Geographic region of COB research}

In this section, the articles were classified according to their regional scope. We identify the country of interest emerging from each article and provide their reference number of publications in each classification, and share in total articles. In Table 2, it is observed that 33 articles (24\%) do not have a specific geographical focus, while the remaining 102 articles $(76 \%)$ focus on at least one country in Asia, Oceania, Europe, or North America. Our literature search did not yield any COB articles focusing on Africa or South America. Articles that study more than one country are classified under each country studied in order to present comprehensive geographic coverage. These articles appear more than once in Table 2.

Of the articles with a regional focus, the largest number are focused on the Netherlands (26\%), followed by China (13\%), Germany (10\%), Belgium (10\%), and the USA (8\%). Articles that focus on European countries account for the majority of reviewed articles, indicating strong $\mathrm{COB}$ interest and/or activity within Europe. Konings et al. (2010) explain this phenomenon as the result of a continuous and strategic investment made by European countries over the past three decades to stimulate COB development in Northwestern Europe (including Netherlands, France, and Belgium), so as to accelerate a container transportation modal shift from truck to barge. Seventeen articles study COB transportation in China, making it the country with greatest COB interest and/or activities in Asia. Container on barge transport on Yangtze River has been in a rapid growth phase since the Chinese government issued the 2016 National Plan for the Yangtze River Economic Belt Development (Yang et al. 2021).

There are 15 articles that focus on more than one country. Konings (2006), Konings and Priemus (2008), and Konings and Maras (2011) all focus on the development of COB transportation along the Rhine River (France, Switzerland, 


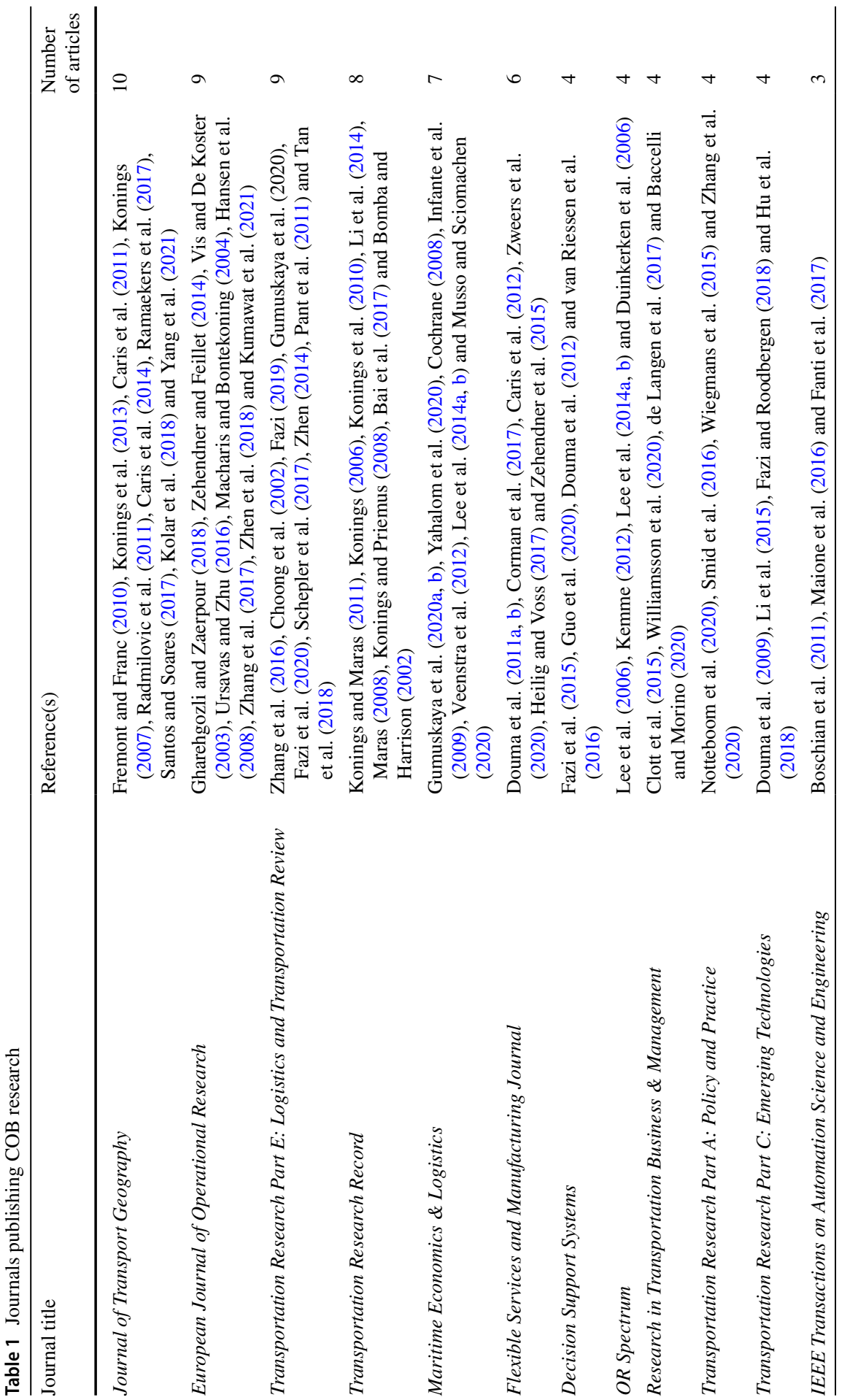

称。 


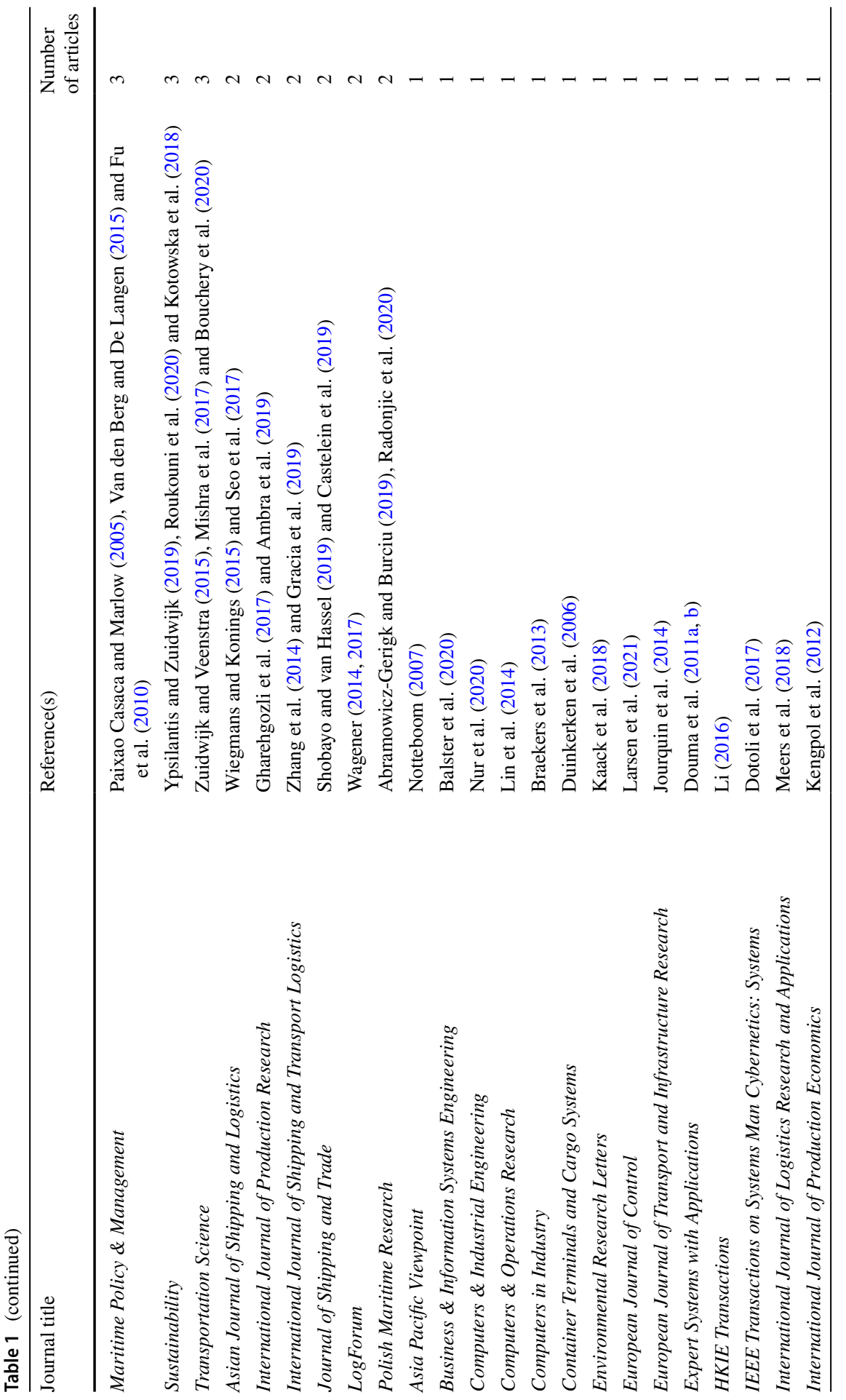




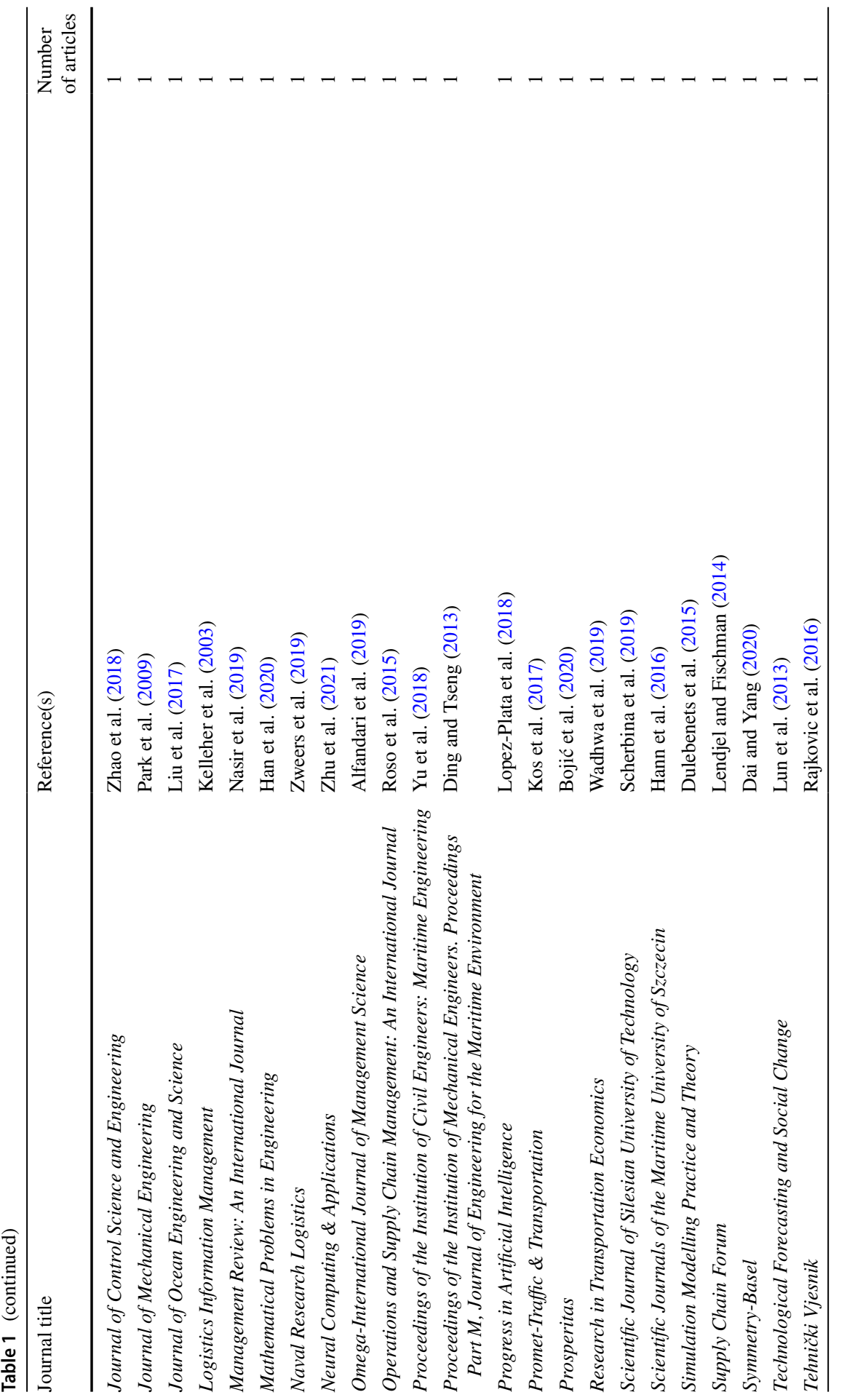

站 


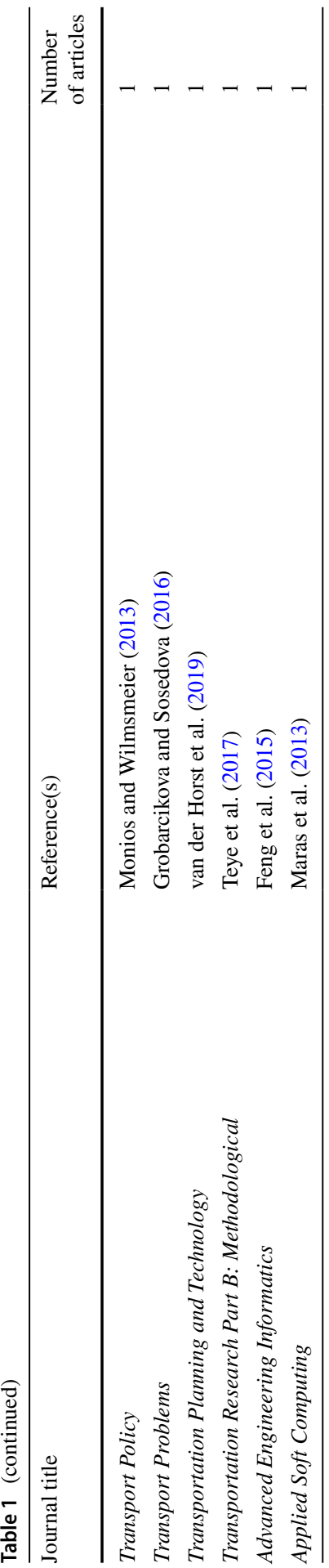




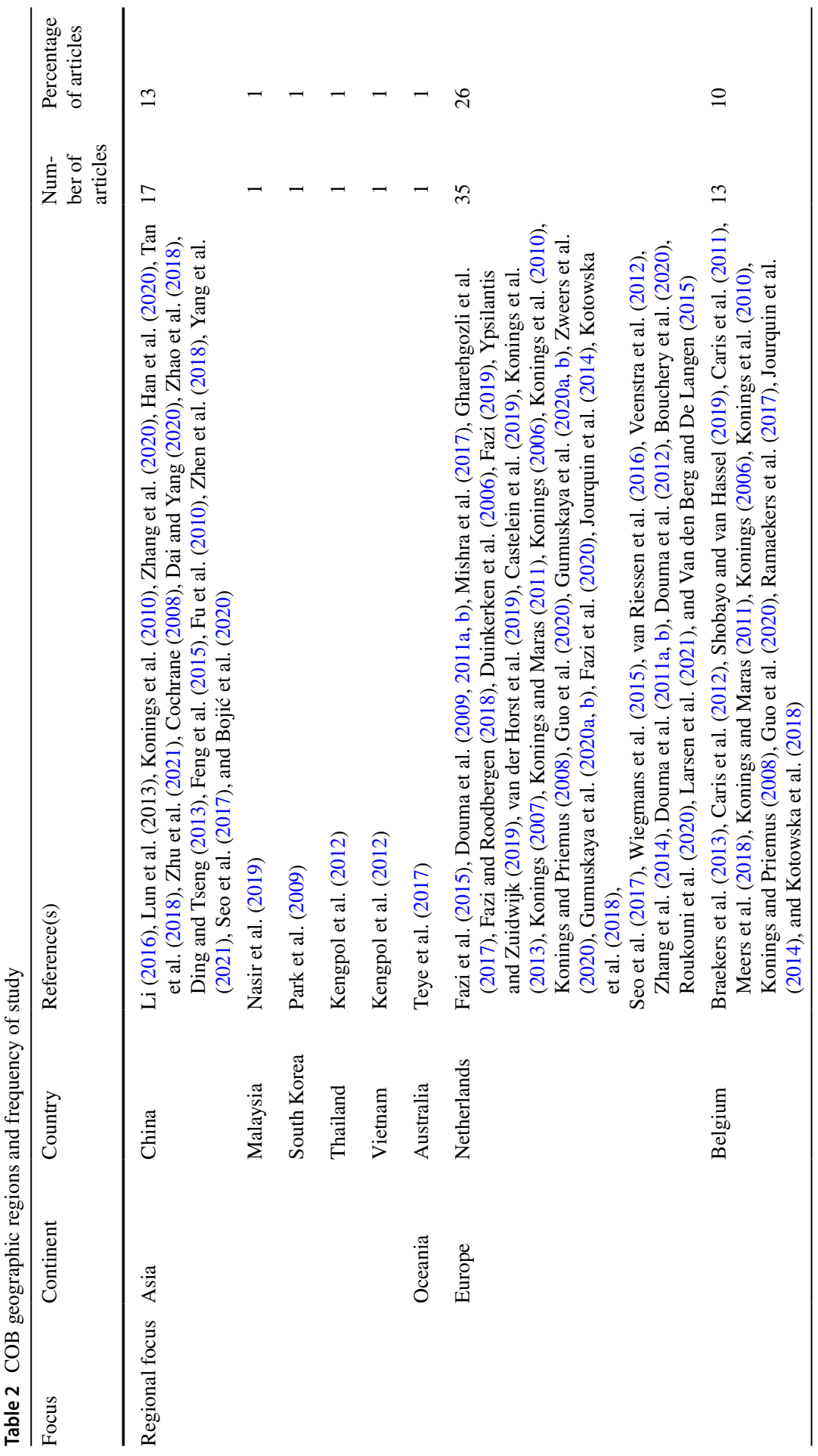

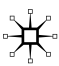




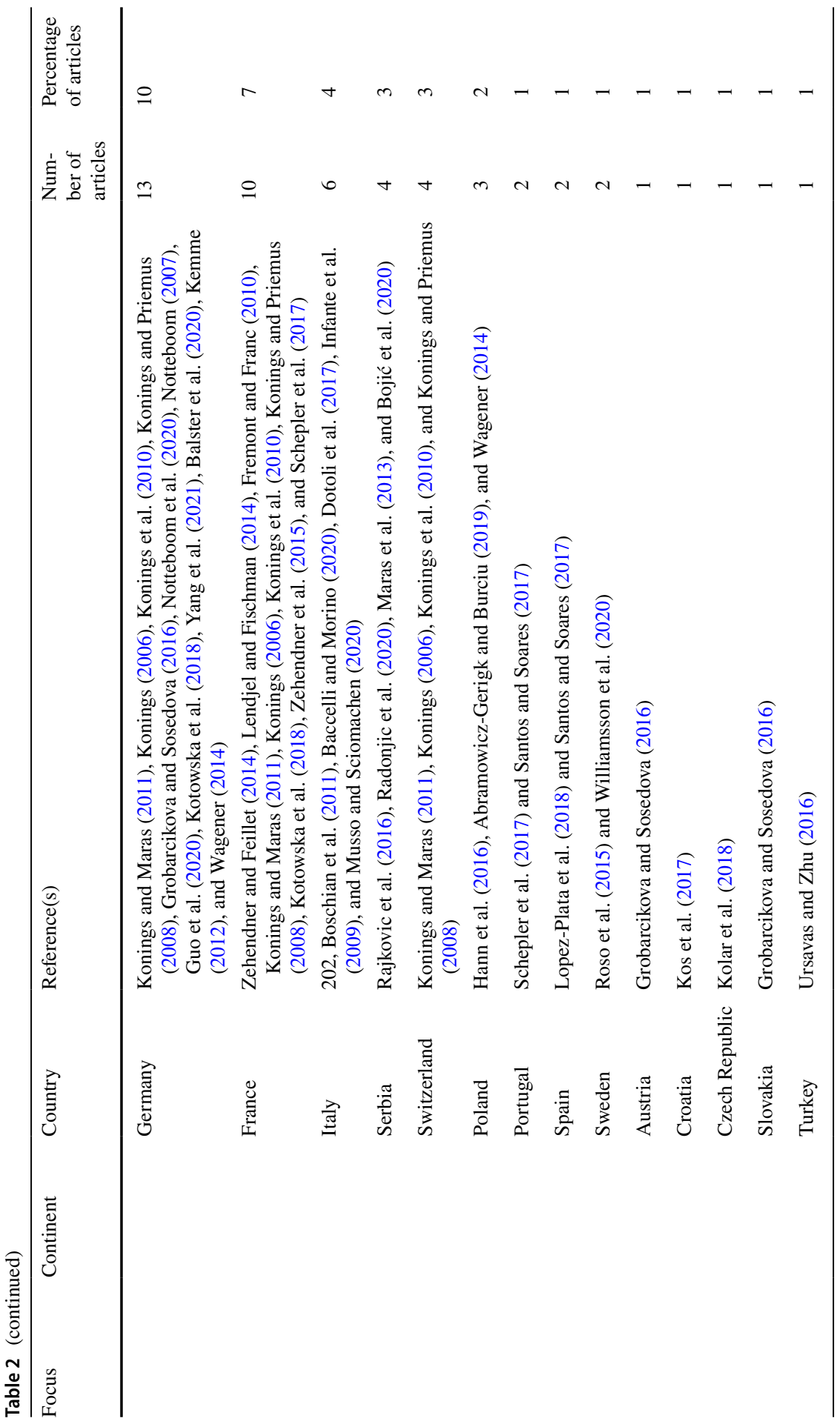




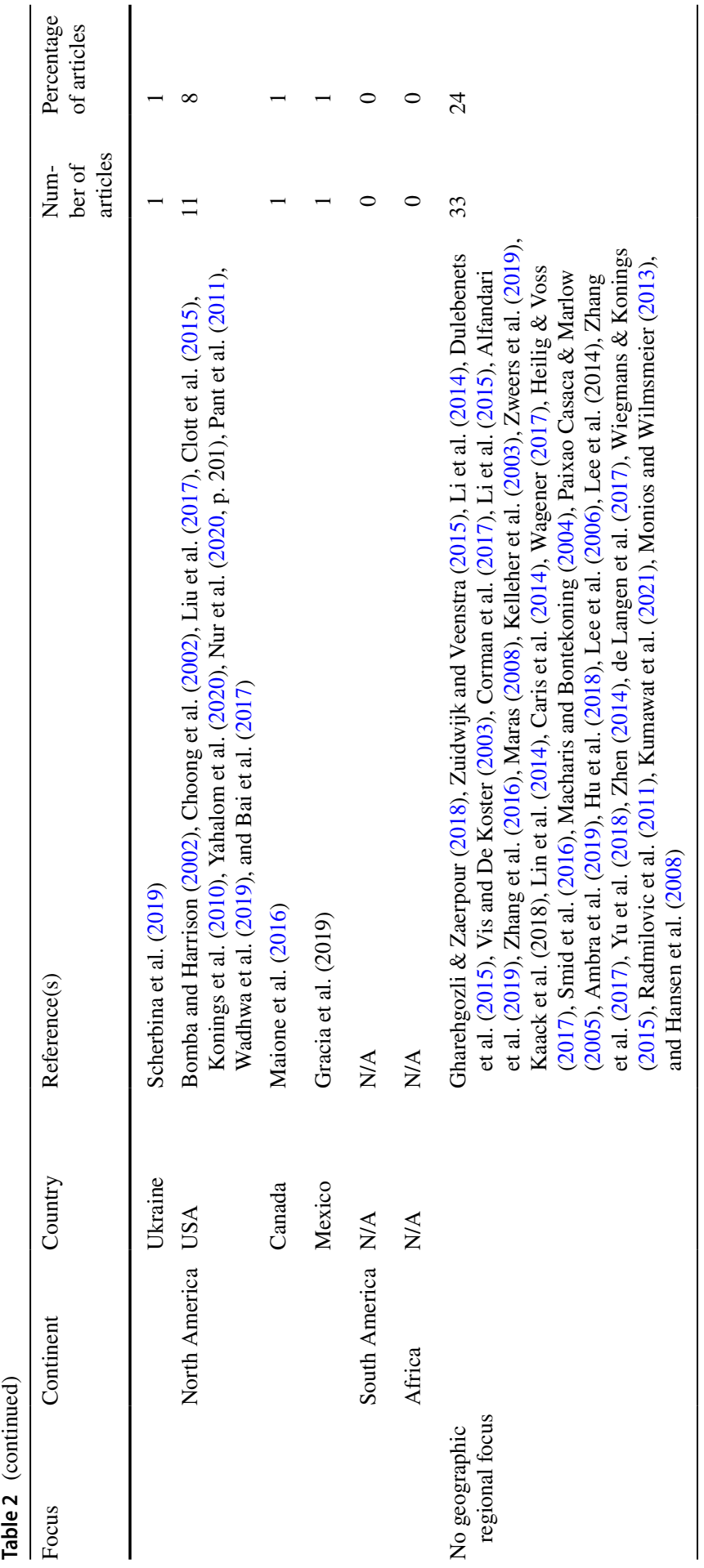

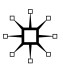


and Germany), the port areas of Rotterdam (Netherlands), and the port area of Antwerp (Belgium). Konings et al. (2010) compare COB development in Texas (USA) and the Port of Rotterdam (Netherlands) to conclude that COB is a mature mode of transportation in the Netherlands while it is still in an early phase in the USA. Notteboom (2007) and Notteboom et al. (2020) explore a general pattern of COB business development, by comparing COB development conditions between the Rhine River (Germany, Belgium, France, Netherlands, and Switzerland) and the Yangtze River (China). They suggest that COB development in single-river systems seems to follow a similar path, although heavily influenced by geographic conditions, local supportive policies, development strategies, and other factors. Grobarcikova and Sosedova (2016) focus on the upper area of the Rhine River, specifically the Danube Canal (Germany, Austria, and Slovakia). They conclude that current COB research studying the Danube Canal does not consider the major challenge of unstable water level and how this limits COB development and submit this challenge should not be omitted in future research.

The observations from Table 2 show that (1) COB studies are concentrated within a limited number of developed or rapidly developing countries with favorable inland waterway resources, i.e., Germany, Belgium, France, the Netherlands, China, and the USA, and (2) regional characteristics of COB are of obvious interest since the vast majority of $\mathrm{COB}$ articles $(76 \%)$ have a regional focus.

\section{Research questions studied in COB literature}

In this section, the COB-related research questions studied in the 135 selected articles are reviewed. Our review indicates that the $\mathrm{COB}$ research questions studied globally are quite diversified. In Table 3, there are five classifications and 23 distinct research questions listed with their corresponding author information, number of articles, and share in total articles. Among the five classifications, almost onethird of the selected articles (32\%) are categorized as intermodal transportation, followed by $21 \%$ of articles classified as terminal operations and $18 \%$ articles classified as $\mathrm{COB}$ performance. Furthermore, at a more detailed level, the most frequently researched topic is intermodal transportation network design (16\%), followed by the ship routing problem $(14 \%)$, barge container terminal operations $(13 \%)$, and comparative strategies for COB development (12\%). In addition, barge handling efficiency is studied in 14 papers (10\%), and empty container repositioning by barge is studied in 8 articles (6\%). The remaining $\mathrm{COB}$ research topics are studied less than $5 \%$ among the reviewed articles.

Twenty-two of the reviewed 135 articles (16\%) study intermodal transportation network designed for or integrated with COB transportation. This involves carriers (barges, trains, and trucks), producers, customers, and terminal operators who ship cargo between deep-sea ports and inland ports. More than one decade earlier, Kelleher et al. (2003) discussed the possibility of developing a more efficient and environmentally friendly intermodal transportation system that utilizes inland waterway resources. As shown in Fig. 1, COB-related transportation has gained increasing attention since 2014, showing increasing support for Kelleher's vision. Li et al. 


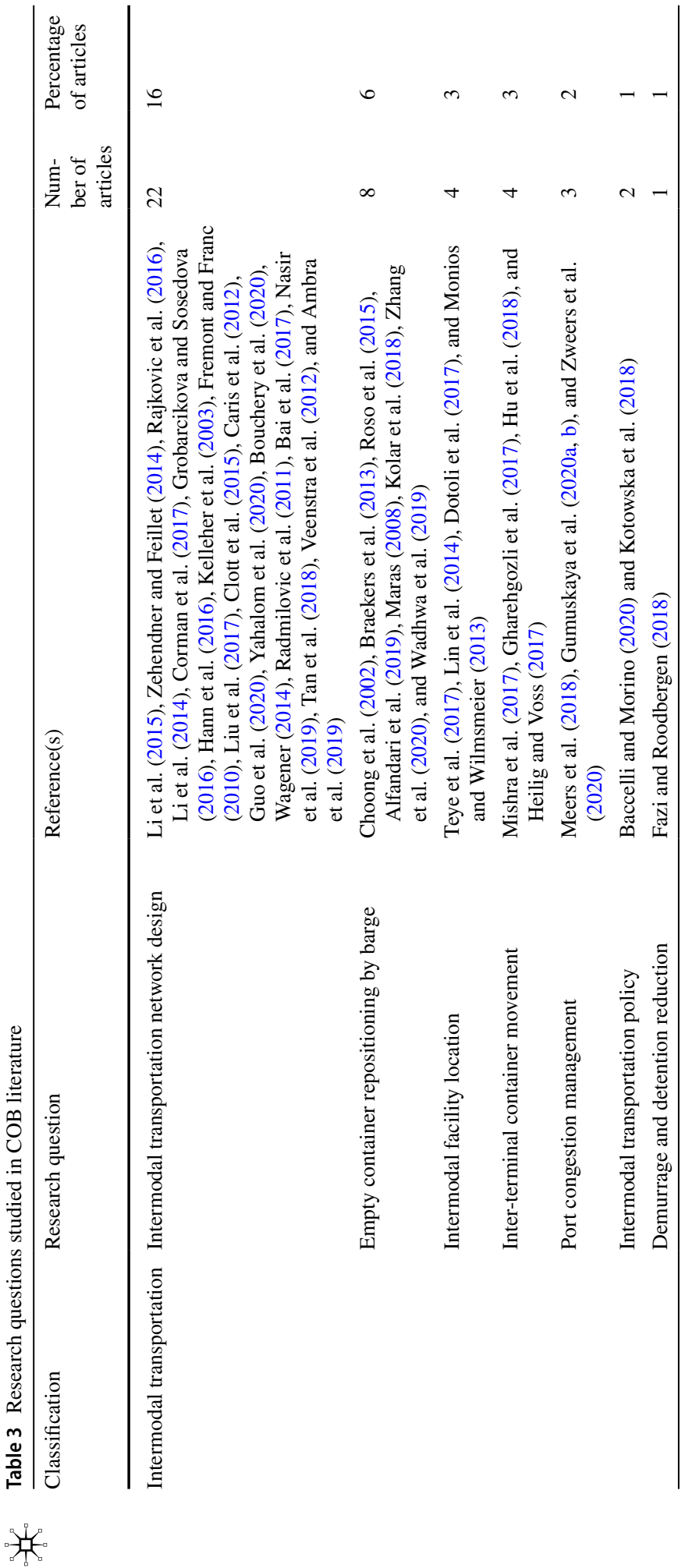




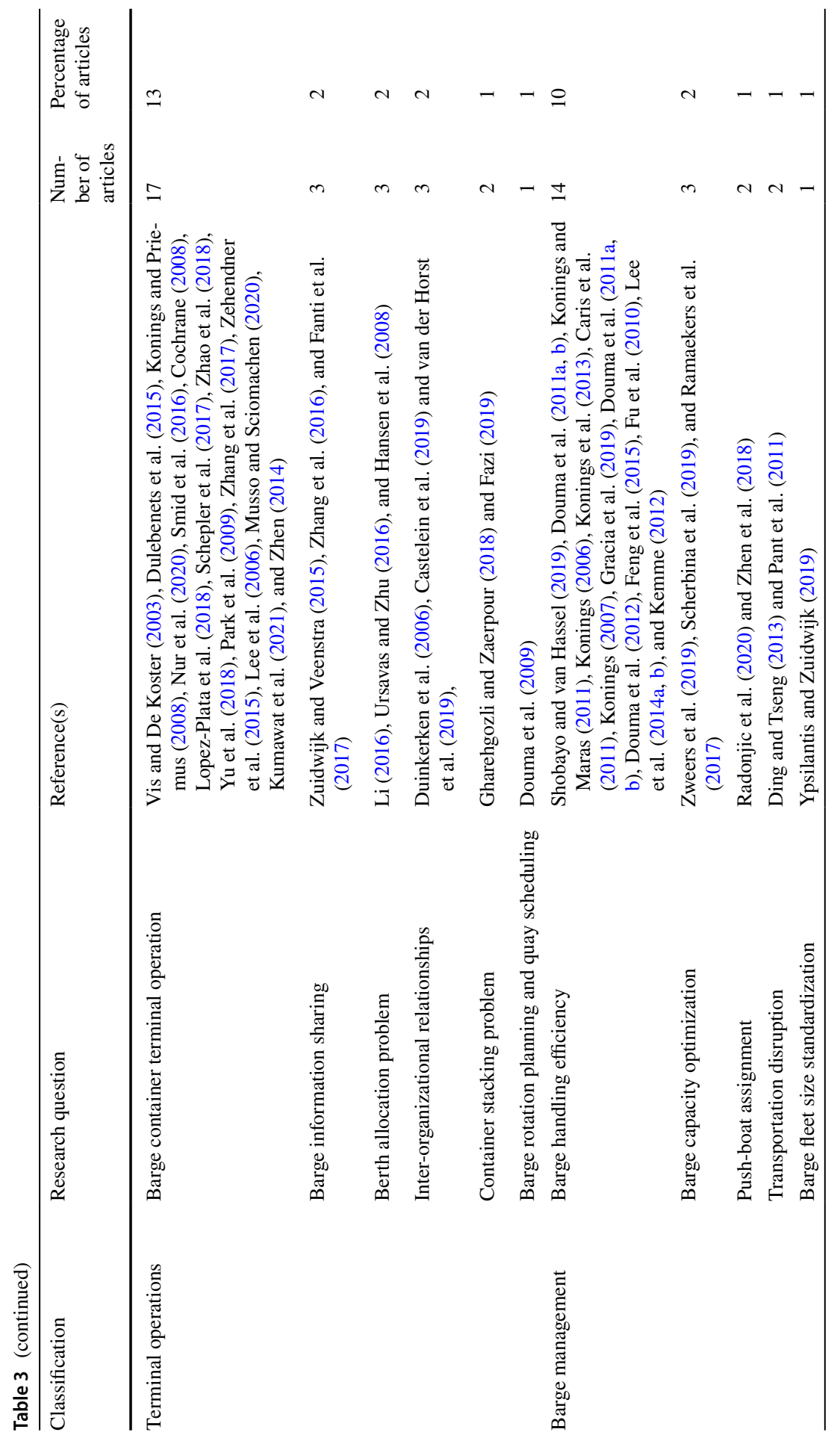




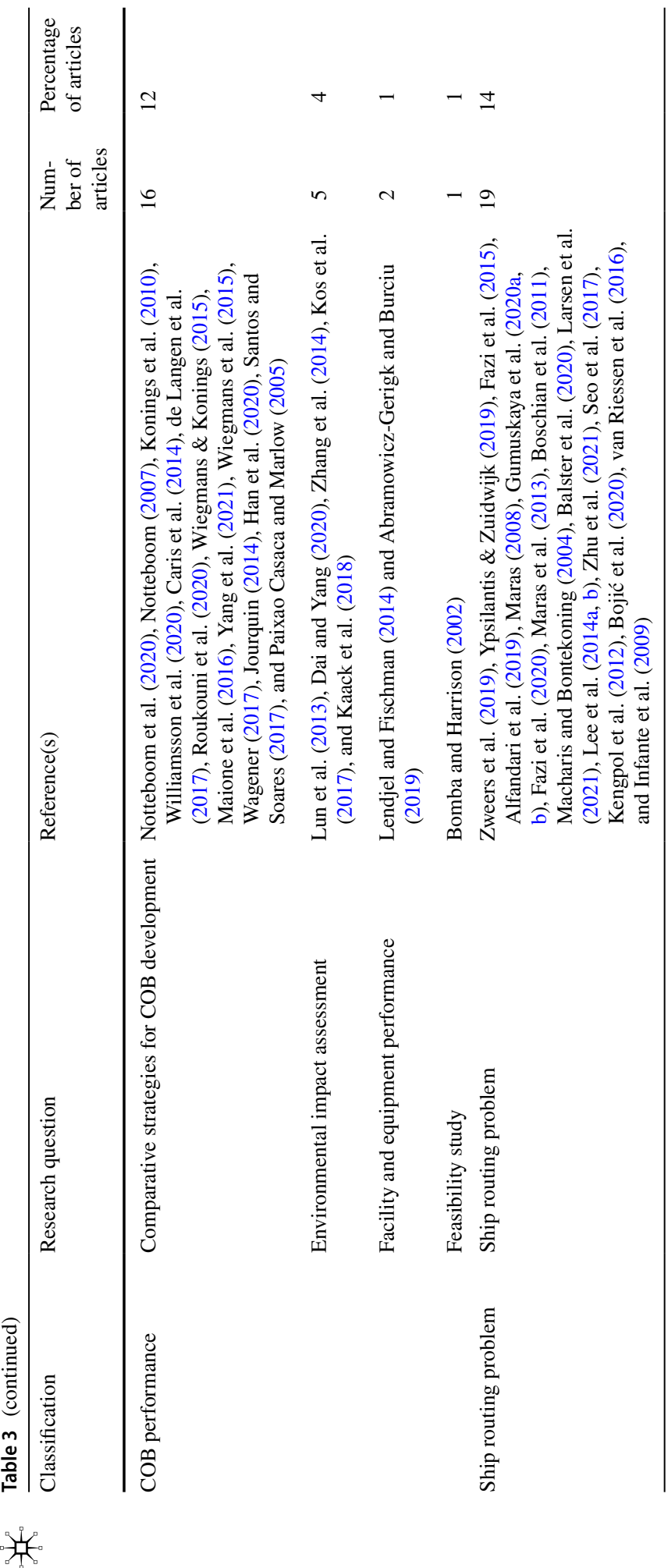


(2015) present a multilevel container flow planning model to study characteristics of an intermodal transportation network, including mode changes, capacity constraints, and scheduling time. The model successfully lowers the intermodal container transportation cost in different simulation scenarios. Ocean shipping is connected to inland transport by combining truck, rail, and barge transportation. Li et al. (2014) point out that, by implementing COB transportation as a mode to transport containers between deep-sea terminals and inland waterway terminals, container distribution efficiency at seaports can be increased and the operational pressure can be reduced on terminals when faced with highly increasing cargo transport demand. Corman et al. (2017) apply a presumed consumer equilibrium principle that includes both single and multiple container units to be transported by multiple modes. Their model indicates that $\mathrm{COB}$ can compete with truck and train under certain conditions with appropriate policy support, accessibility to waterway, and time-insensitive cargoes. Grobarcikova and Sosedova (2016) attempt to design and merge a COB transportation chain into the existing Rhine-Danube intermodal transportation system but fail, due to unstable water level and insufficient infrastructure. Hann et al. (2016) analyze the effects of main transportation parameters of the river-land intermodal transportation on the Oder Waterway in Poland. Nasir et al. (2019) interviewed container transportation professionals in Malaysia and found $\mathrm{COB}$ can be crucial to building an improved intermodal transportation network in future.

There are 19 articles (14\%) that study the COB ship-routing problem. The shiprouting problem is receiving attention from researchers who seek to manage the increasing requirement from seaport terminals to distribute containers more efficiently to inland ports (Zweers et al. 2019). Maras (2008) develop an inland waterway COB shipping route model that accommodates port calls for empty containers. Ypsilantis and Zuidwijk (2019) build a mixed-integer linear programming (MILP) model to optimize barge fleet size and barge routes on inland waterways and investigate the suitability of COB transportation, while considering cost savings and transportation sustainability. Fazi et al. (2020) optimize container IWT between dry ports and seaports in the Port of Rotterdam area aiming to achieve economies of scale and diversion of traffic from road transport.

Seventeen papers (13\%) study the barge container terminal operations to increase operational efficiency in terms of operational time and/or cost. Dulebenets et al. (2015) evaluate if terminal operation efficiency can be improved if containers are stacked on a barge for next transshipment instead of being moved internally to the storage yard. Smid et al. (2016) analyze the operation cost sensitivity of different size container terminal and show that larger terminals generally have a greater container flow throughput to generate economies of scale. Lopez-Plata et al. (2018) optimize the internal delivery vehicle scheduling with a customized heuristic algorithm that considers real-world scenarios and disruptive events.

Sixteen papers (12\%) compare the strategies for COB development. Notteboom et al. (2020) conduct a comparison study between the Rhine and Yangtze rivers and identify that the traffic distribution, regional economies, and terminal ownerships are the main factors caused different COB development path between them. Wiegmans and Konings (2015) compare barge container transportation with truck-only mode to conclude that, with the exception of handling large flow of containers in 
small inland waterway terminals, COB-integrated intermodal transportation would gain obvious competitiveness over truck-only mode. Williamsson et al. (2020) compare two attempted COB development cases from Sweden to unveil that policy support from local government can significantly boost COB development.

Interestingly, eight studies (6\%) focus on the empty container repositioning by barge. The efficient transport of empty containers by barge is getting more attention in recent years since it may significantly enhance a shipping company's profitability by reducing empty container storage and/or leasing costs (Maras 2008; Alfandari et al. 2019). Roso et al. (2015) draw comparisons between empty container transportation by barge and by truck in terms of economic effects, transportation time efficiency, and environmental sustainability. Braekers et al. (2013) build a case study of the Port of Antwerp and design a decision support tool of COB transportation that takes empty container barge transportation into consideration.

The research questions studied in COB literature vary widely. It appears that COB development relies heavily on the natural geographical waterway conditions and infrastructure investment. These unique functional and structural characteristics drive a variety of challenges encountered during COB development and motivate investigations in the success factors and paths for COB development. In addition, COB transportation seldom operates on its own but connects to an existing intermodal transportation network where multiple parties involved in development and operations. Therefore, a multitude of complex COB research challenges are derived from complicated real-world applications, reflecting the need for enhancing operation and coordination efficiency.

\section{Methodological approaches employed in COB research}

The methodological approaches employed in the articles of our sample are categorized in this section and in Table 4. Sixteen distinct methodological approaches are identified and are presented along with the article reference, number of articles, and share in total articles of each category. Based on our review, the most frequently applied methodological approach to COB research is simulation $(23 \%)$, followed by case study analysis (19\%) network optimization (11\%), economic analysis (10\%), and mixed-integer programming (10\%). Studies that apply more than one methodology appear multiple times in Table 4.

Among the methodologies, 31 out of the 135 articles (23\%) implement a simulation approach. Zehendner and Feillet (2014) combine simulation with mixed-integer programming model to minimize the overall delay time at an intermodal container terminal by finding optimal solutions to allocate truck and straddle carries for internal container movement between yard and different transportation modes (train or barge). Li et al. (2015) propose a linear programming model to control and reassign container flows in an intermodal transportation network with multiple objectives, to minimize transportation time and costs. The simulation results from their predesigned scenarios show that the model works well under different levels of market demand, with a certain allowed level of demand prediction errors. Caris et al. (2011) conduct a discrete event simulation to study the cooperation between 


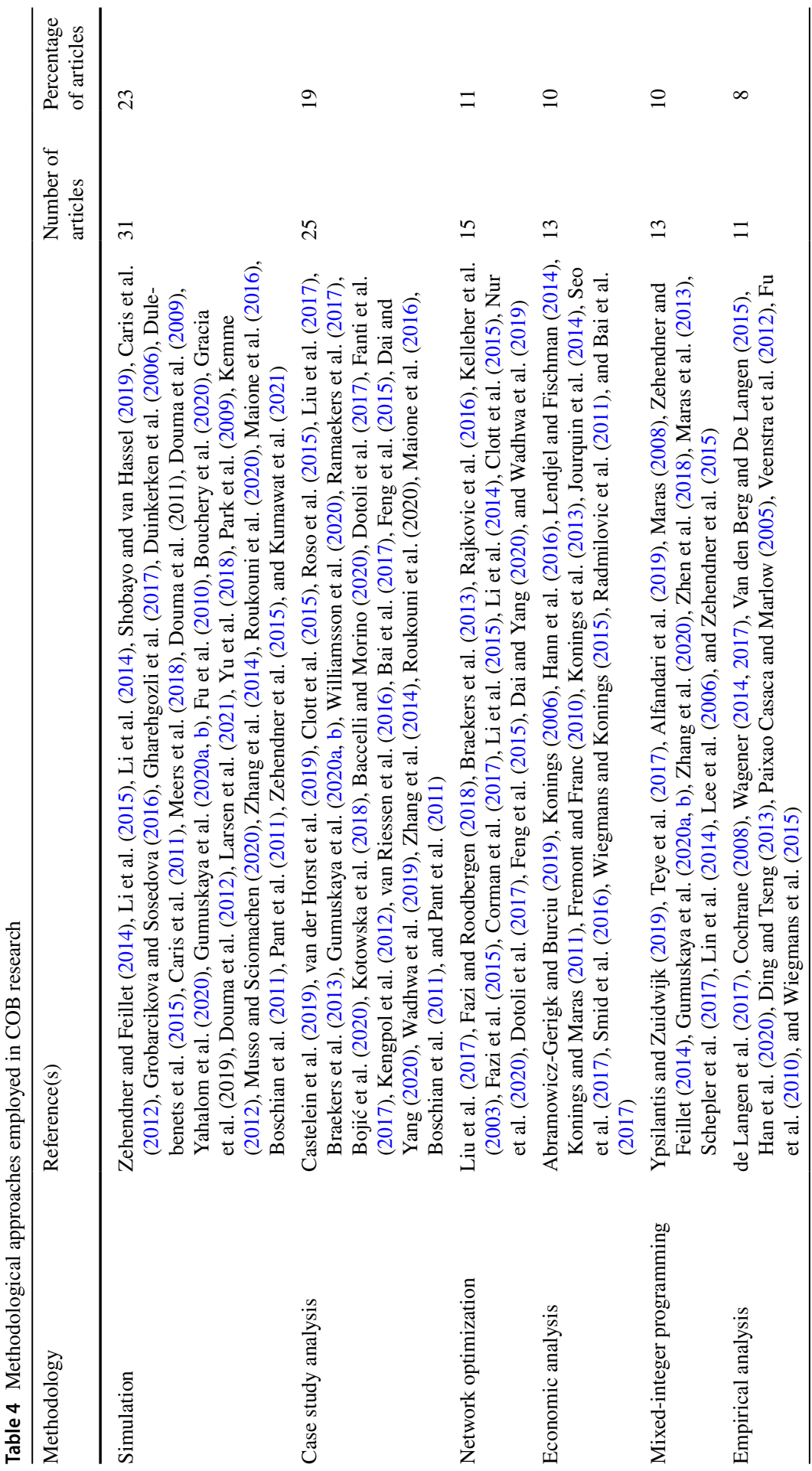




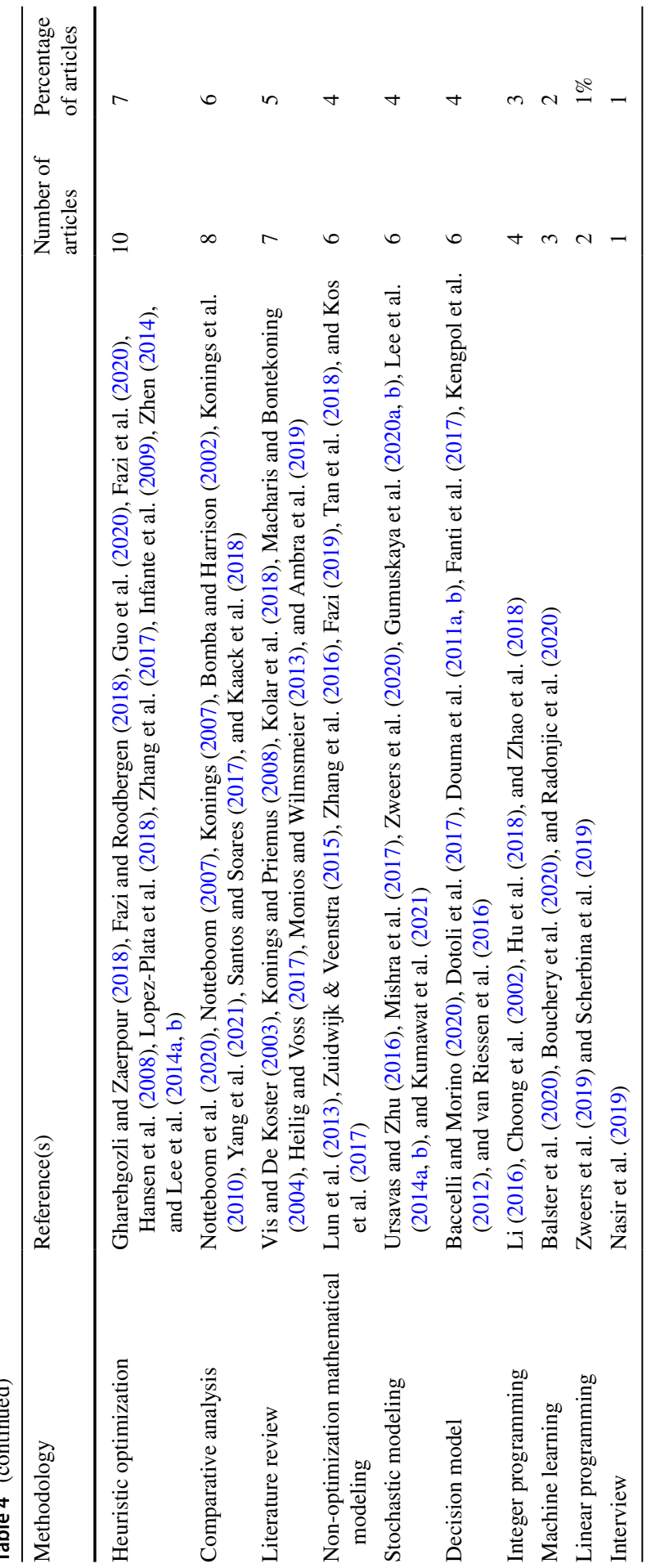

我这 
inland waterway terminals, to bundle container flows in intermodal barge transportation. The authors argue that, through cooperation, inland waterway terminals could generate economies of scale while reducing average barge waiting time at terminals. However, a set of bundling measures is required in future research to improve transportation efficiency. Furthermore, Caris et al. (2012) study the application of bundling strategies on interterminal container transportation that moves containers between terminals with truck, barge, and/or automated guided vehicle. By using game theory combined with simulation experiments, the authors argue that bundling strategies can bring economic benefits only when high demand occurs at terminals.

Case study analysis is the second most frequently employed methodological approach found in COB research, comprising $19 \%$ of our sample. Castelein et al. (2019) conduct a case study of the Port of Rotterdam to identify the underlying problems caused by interorganizational cooperation and competition under pressure. Their case study reveals the significance of mutual trust, value sharing, and unity among intermodal transportation parties, to maintain a healthy balance between cooperation and competition. Van der Horst et al. (2019) also conduct a case study on the COB transportation in the Port of Rotterdam and conclude that the different ownership of port or terminal properties and the lack of decision-making authority from $\mathrm{COB}$ parties are the two main drawbacks that limit further COB development, even with supportive government policies. Clott et al. (2015) explore the operational and political challenges of containerized soybean transportation based on a case study. They argue that a main factor causing an increased total cost in containerized soybean export in the USA is barge delay, which could be improved by employing suitable optimization tools from private businesses and streamlined government decision-making processes.

In addition to simulation and case study analysis, more than a third of our sample (36\%) apply an optimization-based approach. To specify the type of optimization used in each study, optimization is further divided into network optimization (11\%), mixed-integer programming (10\%), heuristic optimization (7\%), stochastic modeling $(4 \%)$, integer programming $(3 \%)$, and linear programming $(1 \%)$, as presented in Table 4.

Network optimization (11\%) is the most commonly applied optimization method applied in reviewed COB studies. Liu et al. (2017) formulate a (national) intermodal network model of barge, truck, and train container transport to optimize the total transportation costs of the USA's containerized soybean flows. Fazi and Roodbergen (2018) build a network model for transporting containers between seaports and inland ports, aiming to minimize transportation costs, demurrage, and detention time while using on-time delivery as the main constraint. Braekers et al. (2013) utilize a network model to determine shipping routes for roundtrips between seaports and multiple inland ports in Northwestern Europe (primarily, Netherlands and Belgium). The objective of their network optimization model is to maximize transportation profitability while considering the empty container repositioning problem. Rajkovic et al. (2016) use network optimization to minimize container transportation costs and time from the Port of Shanghai (China) to Serbia based on a simplified intermodal transportation network that includes COB. Fazi et al. (2015) minimize the penalty of barge docking and underutilization along with transportation costs. In 
addition, network optimization is observed to be a popular method for studying the decision-making process for selecting routes and controlling container flows in COB-involved intermodal transportation (Corman et al. 2017; Li et al. 2014, 2015).

Other optimization approaches [mixed-integer programming (10\%), heuristic optimization (7\%), stochastic modeling (4\%), integer programming (3\%), and linear programming (1\%)] are implemented among researchers, due to the various aspects of their $\mathrm{COB}$ research questions and/or applications described in Table 3. In general, the majority of these articles seek to minimize transportation costs, time, or distance or maximize profit under a given decision scenario. In addition to these optimization approaches, nonmathematical methodological approaches employed less frequently in the COB literature are empirical analysis (8\%), comparative analysis (6\%), and literature review $(5 \%)$.

Observing Table 4, we identify a pattern where earlier papers (published before 2011) favor optimization methods more than recently published papers (after 2011). The more recent research is more likely to implement case study analysis, simulation, and empirical analysis. Due to the increasing complexity of competitors and collaborators relations among $\mathrm{COB}$ parties (i.e., shippers, operators, customers, port authorities, government, other stakeholders), these complex interrelationships may require simulation, case study, and/or empirical approaches to achieve robust representation. Moreover, we observe that new and innovative trending approaches are used in recent publications. For instance, four articles implement game theory and Nash equilibrium to study the behavior of market players in COB-involved intermodal transportation networks (Douma et al. 2012; Bouchery et al. 2020; Roukouni et al. 2020; Caris et al. 2012). Three papers published in 2020 apply machine learning to predict estimated time of arrival and market demands in COB transportation (Balster et al. 2020; Bouchery et al. 2020; Radonjic et al. 2020).

\section{Advantages of COB}

In this section, the 135 articles are reviewed to identify the advantages of COB. As presented in Table 5, 35 (26\%) articles mention one or more advantages of COB, while the remaining articles (74\%) do not specifically discuss any COB advantages. Twenty-five out of 135 articles (19\%) discuss the low cost of COB transportation. Environmentally friendly is the second-most frequently mentioned advantage, with 15 out of 135 articles (11\%), followed by 7 articles (5\%) that debate the advantage of reducing road congestion by promoting COB. In addition, seven articles (5\%) address how $\mathrm{COB}$ could help in achieving economies of scale, and six articles (7\%) discuss the reliability of $\mathrm{COB}$ as an important advantage. The remaining advantages are discussed in three or fewer articles.

Low cost appears to be the most significant advantage of COB transportation, with $19 \%$ of the articles addressing it. Some of the researchers were able to identify reasons why this is the case. As Zweers et al. (2019) argue, barge transportation can significantly reduce the total transportation costs owing to the following two reasons: (1) economies of scale: by loading as many containers as possible onto the barge, shipping costs could be decreased between $20 \%$ and 


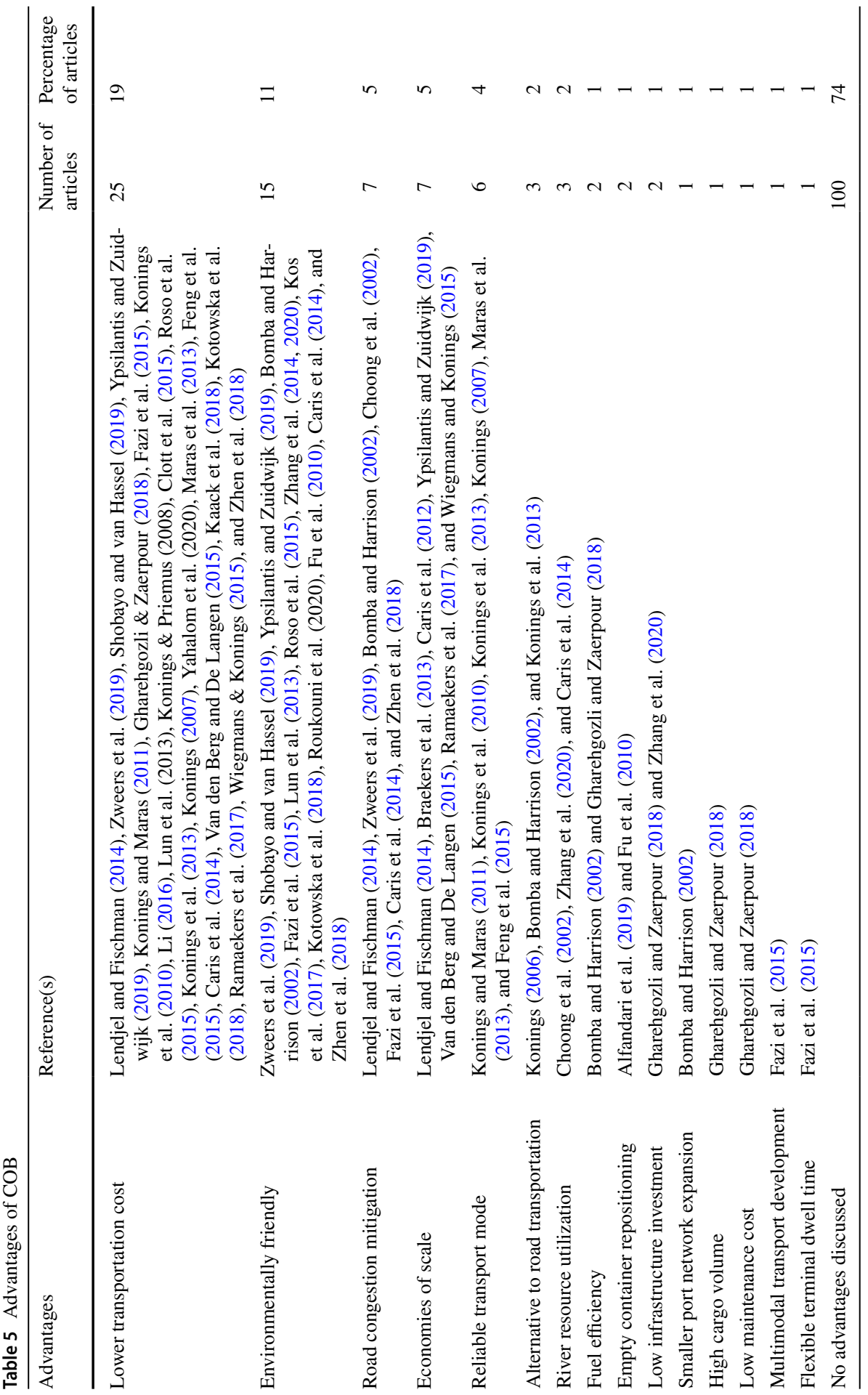


$50 \%$ compared to truck or rail; and (2) an estimated $40-80 \%$ of truck container transportation costs are generated while transporting between inland destinations. Therefore, increasing the market share and distance covered by COB could significantly reduce this share of costs in containerized intermodal transportation. Shobayo and van Hassel (2019) present similar findings showing that COB provides seaports with an alternative to directly move containers through inland waterways without wasting time on congested roads; thus, the cost per TEU declines, especially when transporting larger quantities of cargo. Maras et al. (2013) find several conditions of COB cost advantage in intermodal transportation: (1) containers should be transported by large-sized barges to generate economies of scale; (2) when shipping regular containers, empty container repositioning should also be scheduled to utilize all capacity left on the barge to reduce the cost of purely shipping empty containers; and (3) berth allocation and route planning should be optimized to avoid port penalty costs as much as possible. Gharehgozli and Zaerpour (2018) provide an external costs comparison chart (measured in cents per ton-kilometers) and argue that barge container transportation (0.27) has the lowest fuel consumption when compared with truck (0.8) and train (2.01), and in addition, barge infrastructure costs are approximately $25 \%$ of the other two modes. Konings et al. (2010) indicate that container stacking height and terminal size also contribute to the comparatively low cost of barge transport. Furthermore, Lun et al. (2013) consider that barge transportation produces less environmental pollution, which can lead to a lower external cost.

There are 15 articles (11\%) that describe environmentally friendly as another major advantage of $\mathrm{COB}$ transportation. Although most nations have their own standards to measure the sustainability of different transportation modes, "external costs" is recommended by the European Commission to evaluate the environmental sustainability of transportation modes. In general, most researchers only mention the environmentally friendly benefit of COB without going into depth. However, Lun et al. (2013) study the external costs of barge container transportation and conclude that the external cost of barge container transportation is much lower than that of regular containership in Hong Kong. Roso et al. (2015) indicate that using COB instead of trucks to transfer empty containers would further reduce fuel consumption; thus, environmental damage would be further decreased. Fu et al. (2010) argue that $\mathrm{COB}$ has a low fuel efficiency and pollutes less harmful particles into the air. Kotowska et al. (2018) promote COB as the best choice for modal shift from truck container transportation to decrease negative impacts on environment by reducing emission, noise, and land utilization.

Reducing road congestion is also well debated among seven articles (5\%). Road congestion is a major problem in seaport areas that creates container vehicles delay, but intermodal transportation including $\mathrm{COB}$ can mitigate this situation (Zweers et al., 2019). Earlier, Bomba and Harrison (2002) advise that COB services launched in the Port of Rotterdam provide a great example for moderating road congestion in the port areas of New York and New Jersey in the USA. More recently, Lendjel and Fischman (2014) attempt to design a congestion-free container transportation network with the combined modal of truck and barge transportation for cities with high density of population in France. The situation here is quite the same; most articles 
simply mention that $\mathrm{COB}$ reduces road congestion without in-depth explanation or data to confirm this advantage.

We make three general observations from Table 5: (1) low cost is identified as the top advantage of COB transportation (it may be of interest to note that most papers omit discussing the disadvantage that time-sensitive cargo is not commonly transported by COB); (2) although barges appear to be fuel efficient and eco-friendly, environmental issues of the other modes (truck, rail, automated guided vehicles, etc.) involved in $\mathrm{COB}$ intermodal transportation need further consideration, to quantify COB external costs advantages; and (3) empty container repositioning by COB appears to be effective in further reducing road congestion in port areas, in addition to $\mathrm{COB}$ transport of loaded containers.

\section{COB success factors}

The key success factors of $\mathrm{COB}$ are discussed in this section. Our literature review identifies $11 \mathrm{COB}$ success factors as listed in Table 6, along with their corresponding reference and the number and percentage of articles. Based on the findings observed in Table 6, infrastructure investment is the most notable factor, with 11 articles $(8 \%)$ discussing this success factor. This factor is followed by container market growth (nine articles, 7\%), navigability of inland waterways (seven articles, 5\%), availability of inland waterways (six articles, $4 \%$ ), and terminal operations efficiency (six articles, 4\%). Moreover, hinterland access of major seaports and enabling government policies are COB success factors that appear in five (4\%) articles. Other COB success factors are mentioned in two or fewer articles.

Although the availability and navigability of inland waterways are not the most frequently mentioned $\mathrm{COB}$ success factors, these two factors are clearly a necessary factor of successful COB development. Like Notteboom et al. (2020, p. 2) states, "the potential role and spatial configuration of a container barge network is also strongly entwined with the availability and navigability of the inland waterways and canals." In addition, availability of inland waterways with access to major cities with large scale of economy will gain more competitive advantages for COB service (Notteboom 2007).

Infrastructure is the most frequently mentioned key factor in COB success. Without the support of good inland waterways infrastructure capacity, COB transportation is not able to handle enough TEUs in a required time (Fremont and Franc 2010). Van der Horst et al. (2019) illustrate that European countries have been working collaboratively with port authorities and private organizations to increase the effectiveness of seaport and inland waterway port infrastructure usage, indicating that more investment in COB infrastructure would maintain high levels of transportation safety, reliability, material handling efficiency, and sustainable COB services. These benefits could generate a positive loop to reduce future infrastructure maintenance and investment costs, preserve good waterway accessibility, and reduce government burden. The recent, continuously increasing investment made by the private sector and provinces alongside the Yangtze River have resulted in updated container barge infrastructure and increased waterway accessibility that have boosted COB 


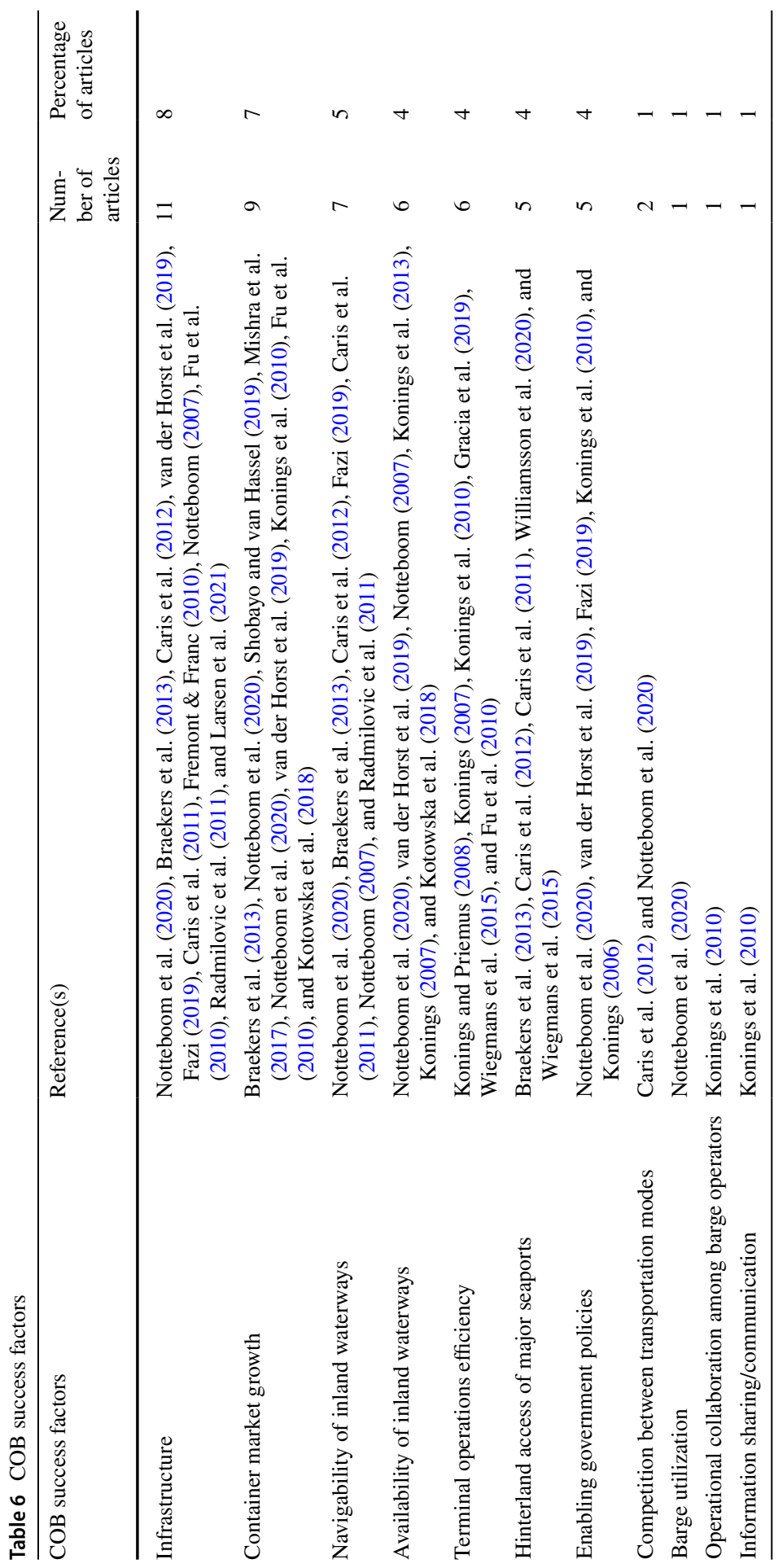


development in this region, making the Yangtze one of the top river systems with COB services (Notteboom et al. 2020).

Rapid COB development benefits from the growth of container market demand and the growth of intermodal transportation. Barge transportation in Northwestern Europe has experienced an average steady growth of $15 \%$ during the past two decades (Braekers et al. 2013). As a result, the total TEU handled by European inland waterway barge transportation increased 37\% in 10 years (2007-2017) (Shobayo and van Hassel 2019). Driven by the rapid international trading growth, the Yangtze River handles more than two billion tons of freight every year, which makes fundamental changes to the development of the COB transportation in the inland waterway in China (Notteboom et al. 2020). In addition, the significant increasing in trading between China and the European Union has motivated both European nations and China to make investments and implement policies to launch intermodal transportation including truck, rail, and barge to handle the massive number of containers arriving daily at seaports (Konings et al. 2010). In support of handling the significantly increasing container flow at seaports, barge transport on inland waterways can provide direct accessibility to hinterland ports and a safe, low-cost, and reliable container shipping alternative (Kotowska et al. 2018). As a result, we observe a steady and rapid development of COB transportation in the large seaport area where the inland waterway accessibility and navigability conditions are favorable.

Another key factor in COB success is enabling government policies. As a component of regional economic systems, local policies can have a positive impact on the development of inland waterway transportation including COB services ( $\mathrm{Li}$ et al. 2014). The European shift from traditional container transportation to intermodal transport since the 1990 s is credited to the increasing existence of enabling policies in both public and private sectors (Konings et al. 2010). Since 2010, European policies have increased the percentage of total container transported by inland waterway, which further motivated the development of container barge transportation (van der Horst et al. 2019). In another example, China straightforwardly pushed through the supportive policies for COB development in the Yangtze River Delta area in 2016, which generated the "window of opportunity" and resulted in one of the largest COB transportation markets in the world (Notteboom et al. 2020).

\section{Conclusions and future work}

This literature review and comparative analysis is based on 135 peer-reviewed journal articles with a research focus of Container on Barge (COB) that were selected from maritime and intermodal container transportation studies published between January 2000 and April 2021. This article summarizes and compares these 135 COB studies to help maritime practitioners and researchers understand the current global COB status and provide a comprehensive literature review for future COB research. Important aspects of the reviewed articles are organized into seven categories of interest: (1) annual publication count of COB articles, (2) journals publishing COB research, (3) geographic region of $\mathrm{COB}$ research, (4) research questions studied in $\mathrm{COB}$ literature, (5) methodological approaches employed in COB Research, (6) advantages of COB, 
and (7) COB success factors. Container on Barge research has seen an upward trend over the past decade globally, especially in the last 5 years. The Journal of Transport Geography has published the most COB articles to date. We find that the most prevalent geographic region studied in the reviewed literature is the Netherlands, with $26 \%$ of the articles studying COB in this country. In fact, $53 \%$ of all reviewed articles focus on Northwestern Europe (Belgium, Netherlands, France, and Germany), indicating this region is leading the world in $\mathrm{COB}$ transportation. This literature survey identifies intermodal transportation (32\%) and terminal operations (21\%) as the top two research topics among $\mathrm{COB}$ researchers worldwide. In terms of methodological approach, the most commonly applied method supporting $\mathrm{COB}$ research is simulation, which is employed in $23 \%$ of the reviewed articles, followed by case study analysis with a $19 \%$ employment rate. This review identifies the top three advantages of COB transportation as lower transportation cost, environmentally friendly, and road congestion mitigation. Furthermore, this literature review distinguishes the top two success factors for developing COB transportation, that is, existing infrastructure and container market growth.

The findings in this article will help inform and motivate future growth in research and development of $\mathrm{COB}$ transportation. There are clear advantages and paths to success towards COB implementation, and research in this area can help to support positive change towards $\mathrm{COB}$ as a mechanism for reduced emissions, maintenance, and congestion in transportation networks throughout the world. The outcomes of this review are supporting ongoing work towards the development of a decision analysis tool that will assess the readiness for $\mathrm{COB}$ implementation at port terminals in the USA.

Acknowledgements This material is based upon work supported by the U.S. Department of Transportation under Grant Award Number 69A3551747130. The work was conducted through the Maritime Transportation Research and Education Center at the University of Arkansas.

Disclaimer The contents reflect the views of the authors, who are responsible for the facts and the accuracy of the information presented herein. This document is disseminated in the interest of information exchange. The report is funded, partially or entirely, by a grant from the U.S. Department of Transportation's University Transportation Centers Program. However, the U.S. Government assumes no liability for the contents or use thereof.

Open Access This article is licensed under a Creative Commons Attribution 4.0 International License, which permits use, sharing, adaptation, distribution and reproduction in any medium or format, as long as you give appropriate credit to the original author(s) and the source, provide a link to the Creative Commons licence, and indicate if changes were made. The images or other third party material in this article are included in the article's Creative Commons licence, unless indicated otherwise in a credit line to the material. If material is not included in the article's Creative Commons licence and your intended use is not permitted by statutory regulation or exceeds the permitted use, you will need to obtain permission directly from the copyright holder. To view a copy of this licence, visit http://creativecommons.org/licen ses/by/4.0/.

\section{References}

Abramowicz-Gerigk, T., and Z. Burciu. 2019. Design and operational innovations in adapting the existing merchant river fleet to cost-effective shipping. Polish Maritime Research 26 (4): 157-164. 
Alfandari, L., T. Davidovic, F. Furini, I. Ljubic, V. Maras, and S. Martin. 2019. Tighter MIP models for barge container ship routing. Omega-International Journal of Management Science 82: 38-54. https://doi.org/10.1016/j.omega.2017.12.002.

Ambra, T., A. Caris, and C. Macharis. 2019. Towards freight transport system unification: reviewing and combining the advancements in the physical internet and synchromodal transport research. International Journal of Production Research 57 (6): 1606-1623. https://doi.org/10.1080/00207543. 2018.1494392.

Baccelli, O., and P. Morino. 2020. The role of port authorities in the promotion of logistics integration between ports and the railway system: the Italian experience. Research in Transportation Business and Management. https://doi.org/10.1016/j.rtbm.2020.100451.

Bai, Y., X. Liu, C. Higgins, Y.P. Chiu, and J.H. Chen. 2017. Transportation cost modeling of containerized soybean exports in the United States. Transportation Research Record 2611: 19-31. https:// doi.org/10.3141/2611-03.

Balster, A., O. Hansen, H. Friedrich, and A. Ludwig. 2020. An ETA prediction model for intermodal transport networks based on machine learning. Business \& Information Systems Engineering 62 (5): 403-416. https://doi.org/10.1007/s12599-020-00653-0.

Bojić, Sanja, Nenad Zrnić, Radoslav Rajković, and Branislav Dragović. 2020. Optimization of container transport routes. Prosperitas 7 (1): 31-42.

Bomba, M.S., and R. Harrison. 2002. Feasibility of a container-on-barge network along the Texas Gulf Coast. Marine Transportation and Port Operations: Marine Transportation 1782: 23-30.

Boschian, V., M. Dotoli, M.P. Fanti, G. Iacobellis, and W. Ukovich. 2011. A metamodeling approach to the management of intermodal transportation networks. IEEE Transactions on Automation Science and Engineering 8 (3): 457-469. https://doi.org/10.1109/TASE.2010.2090870.

Bouchery, Y., M. Slikker, and J.C. Fransoo. 2020. Intermodal hinterland network design games. Transportation Science 54 (5): 1272-1287. https://doi.org/10.1287/trsc.2020.0978.

Braekers, K., A. Caris, and G.K. Janssens. 2013. Optimal shipping routes and vessel size for intermodal barge transport with empty container repositioning. Computers in Industry 64 (2): 155-164. https:// doi.org/10.1016/j.compind.2012.06.003.

Caris, A., S. Limbourg, C. Macharis, T. van Lier, and M. Cools. 2014. Integration of inland waterway transport in the intermodal supply chain: a taxonomy of research challenges. Journal of Transport Geography 41: 126-136. https://doi.org/10.1016/j.jtrangeo.2014.08.022.

Caris, A., C. Macharis, and G.K. Janssens. 2011. Network analysis of container barge transport in the port of Antwerp by means of simulation. Journal of Transport Geography 19 (1): 125-133. https:// doi.org/10.1016/j.jtrangeo.2009.12.002.

Caris, A., C. Macharis, and G.K. Janssens. 2012. Corridor network design in hinterland transportation systems. Flexible Services and Manufacturing Journal 24 (3): 294. https://doi.org/10.1007/ s10696-011-9106-3.

Castelein, R.B., H. Geerlings, and J.H.R. Van Duin. 2019. The ostensible tension between competition and cooperation in ports: a case study on intra-port competition and inter-organizational relations in the Rotterdam container handling sector. Journal of Shipping and Trade 4 (1): 1-25. https://doi. org/10.1186/s41072-019-0046-5.

Choong, S.T., M.H. Cole, and E. Kutanoglu. 2002. Empty container management for intermodal transportation networks. Transportation Research Part E Logistics and Transportation Review 38 (6): 423-438. https://doi.org/10.1016/s1366-5545(02)00018-2.

Clott, C., B.C. Hartman, E. Ogard, and A. Gatto. 2015. Container repositioning and agricultural commodities: Shipping soybeans by container from US hinterland to overseas markets. Research in Transportation Business and Management 14: 56-65. https://doi.org/10.1016/j.rtbm.2014.10.006.

Cochrane, R.A. 2008. The effects of market differences on the throughput of large container terminals with similar levels of efficiency. Maritime Economics \& Logistics 10 (1-2): 35-52. https://doi.org/ 10.1057/palgrave.mel.9100190.

Corman, F., F. Viti, and R.R. Negenborn. 2017. Equilibrium models in multimodal container transport systems. Flexible Services and Manufacturing Journal 29 (1): 125-153. https://doi.org/10.1007/ s10696-015-9224-4.

Dai, Q., and J.Q. Yang. 2020. A distributionally robust chance-constrained approach for modeling demand uncertainty in green port-hinterland transportation network optimization. Symmetry-Basel 12 (9): 1492. https://doi.org/10.3390/sym12091492. 
de Langen, P.W., D.M.L. Figueroa, K.H. van Donselaar, and J. Bozuwa. 2017. Intermodal connectivity in Europe, an empirical exploration. Research in Transportation Business and Management 23: 3-11. https://doi.org/10.1016/j.rtbm.2017.02.003.

Ding, J.F., and W.J. Tseng. 2013. Fuzzy risk assessment on safety operations for exclusive container terminals at Kaohsiung port in Taiwan. Proceedings of the Institution of Mechanical Engineers Part M Journal of Engineering for the Maritime Environment. https://doi.org/10.1177/14750 90santos.

Dotoli, M., N. Epicoco, M. Falagario, C. Seatzu, and B. Turchiano. 2017. A decision support system for optimizing operations at intermodal railroad terminals. IEEE Transactions on Systems Man Cybernetics-Systems 47 (3): 487-501. https://doi.org/10.1109/tsmc.2015.2506540.

Douma, A.M., P.C. Schuur, and J.M.J. Schutten. 2011a. Aligning barge and terminal operations using service-time profiles. Flexible Services and Manufacturing Journal 23 (4): 385-421. https:// doi.org/10.1007/s10696-011-9080-9.

Douma, A., M. Schutten, and P. Schuur. 2009. Waiting profiles: an efficient protocol for enabling distributed planning of container barge rotations along terminals in the port of Rotterdam. Transportation Research Part C Emerging Technologies 17 (2): 133-148. https://doi.org/10.1016/j. trc.2008.06.003.

Douma, A., P. Schuur, and R. Jagerman. 2011b. Degrees of terminal cooperativeness and the efficiency of the barge handling process. Expert Systems with Applications 38 (4): 3580-3589. https://doi.org/10.1016/j.eswa.2010.08.147.

Douma, A.M., J. van Hillegersberg, and P.C. Schuur. 2012. Design and evaluation of a simulation game to introduce a multi-agent system for barge handling in a seaport. Decision Support Systems 53 (3): 465-472. https://doi.org/10.1016/j.dss.2012.02.013.

Duinkerken, M.B., R. Dekker, Stgl Kurstjens, J.A. Ottjes, and N.P. Dellaert. 2006. Comparing transportation systems for inter-terminal transport at the Maasvlakte container terminals. OR Spectrum 28 (4): 469-493. https://doi.org/10.1007/s00291-006-0056-1.

Dulebenets, M.A., M.M. Golias, S. Mishra, and W.C. Heaslet. 2015. Evaluation of the floaterm concept at marine container terminals via simulation. Simulation Modelling Practice and Theory 54: 19-35. https://doi.org/10.1016/j.simpat.2015.02.008.

Fanti, M.P., G. Iacobellis, M. Nolich, A. Rusich, and W. Ukovich. 2017. A decision support system for cooperative logistics. IEEE Transactions on Automation Science and Engineering 14 (2): 732-744. https://doi.org/10.1109/tase.2017.2649103.

Fazi, S. 2019. A decision-support framework for the stowage of maritime containers in inland shipping. Transportation Research Part E Logistics and Transportation Review 131: 1-23. https:// doi.org/10.1016/j.tre.2019.09.008.

Fazi, S., J.C. Fransoo, and T. Van Woensel. 2015. A decision support system tool for the transportation by barge of import containers: a case study. Decision Support Systems 79: 33-45. https:// doi.org/10.1016/j.dss.2015.08.001.

Fazi, S., J.C. Fransoo, T. Van Woensel, and J.X. Dong. 2020. A variant of the split vehicle routing problem with simultaneous deliveries and pickups for inland container shipping in dry-port based systems. Transportation Research Part E Logistics and Transportation Review. https:// doi.org/10.1016/j.tre.2020.102057.

Fazi, S., and K.J. Roodbergen. 2018. Effects of demurrage and detention regimes on dry-port-based inland container transport. Transportation Research Part C Emerging Technologies 89: 1-18. https://doi.org/10.1016/j.trc.2018.01.012.

Feng, F., Y.S. Pang, and G. Lodewijks. 2015. Integrate multi-agent planning in hinterland transport: Design, implementation and evaluation. Advanced Engineering Informatics 29 (4): 1055-1071. https://doi.org/10.1016/j.aei.2015.08.001.

Fremont, A., and P. Franc. 2010. Hinterland transportation in Europe: combined transport versus road transport. Journal of Transport Geography 18 (4): 548-556. https://doi.org/10.1016/j.jtrangeo. 2010.03.009.

Fu, Q., L.M. Liu, and Z. Xu. 2010. Port resources rationalization for better container barge services in Hong Kong. Maritime Policy \& Management 37 (6): 543-561. https://doi.org/10.1080/03088 839.2010.514955.

Gharehgozli, A.H., R. de Koster, and R. Jansen. 2017. Collaborative solutions for inter terminal transport. International Journal of Production Research 55 (21): 6527-6546. https://doi.org/10. 1080/00207543.2016.1262564. 
Gharehgozli, A., and N. Zaerpour. 2018. Stacking outbound barge containers in an automated deep-sea terminal. European Journal of Operational Research 267 (3): 977-995. https://doi.org/10.1016/j. ejor.2017.12.040.

Gracia, M.D., J. Mar-Ortiz, and R.G. Gonzalez-Ramirez. 2019. The impact of operational strategies on vessel handling times: a simulation approach. International Journal of Shipping and Transport Logistics 11 (4): 287. https://doi.org/10.1504/ijstl.2019.100488.

Grobarcikova, A., and J. Sosedova. 2016. Design of agent-based model for barge container transport. Transport Problems 11 (4): 95-101. https://doi.org/10.20858/tp.2016.11.4.9.

Gumuskaya, V., W. van Jaarsveld, R. Dijkman, P. Grefen, and A. Veenstra. 2020a. A framework for modelling and analysing coordination challenges in hinterland transport systems. Maritime Economics \& Logistics 22 (1): 124-145. https://doi.org/10.1057/s41278-019-00139-1.

Gumuskaya, V., W. van Jaarsveld, R. Dijkman, P. Grefen, and A. Veenstra. 2020b. Dynamic barge planning with stochastic container arrivals. Transportation Research Part E Logistics and Transportation Review. https://doi.org/10.1016/j.tre.2020.102161.

Guo, W.J., B. Atasoy, W.B. van Blokland, and R.R. Negenborn. 2020. A dynamic shipment matching problem in hinterland synchromodal transportation. Decision Support Systems. https://doi.org/10. 1016/j.dss.2020.113289.

Han, B., M. Wan, and Y. Zhou. 2020. Evaluation of multimodal transport in China based on hesitation fuzzy multi-attribute decision-making. Mathematical Problems in Engineering. https://doi.org/10. $1155 / 2020 / 1823068$.

Hann, M., L. Piotrowski, and K. Wos. 2016. A new concept for utilising the Oder waterway in intermodal container transport. Scientific Journals of the Maritime University of Szczecin-Zeszyty Naukowe Akademii Morskiej W Szczecinie 47 (119): 129-135. https://doi.org/10.17402/159.

Hansen, P., C. Oguz, and N. Mladenovic. 2008. Variable neighborhood search for minimum cost berth allocation. European Journal of Operational Research 191 (3): 636-649. https://doi.org/10.1016/j. ejor.2006.12.057.

Heilig, L., and S. Voss. 2017. Inter-terminal transportation: an annotated bibliography and research agenda. Flexible Services and Manufacturing Journal 29 (1): 35-63. https://doi.org/10.1007/ s10696-016-9237-7.pdf.

Hu, Q., F. Corman, B. Wiegmans, and G. Lodewijks. 2018. A tabu search algorithm to solve the integrated planning of container on an inter-terminal network connected with a hinterland rail network. Transportation Research Part C Emerging Technologies 91: 15-36. https://doi.org/10.1016/j.trc. 2018.03.019.

Infante, D., G. Paletta, and F. Vocaturo. 2009. A ship-truck intermodal transportation problem. Maritime Economics \& Logistics 11 (3): 247-259. https://doi.org/10.1057/mel.2009.6.

Jourquin, B., L. Tavasszy, and L.W. Duan. 2014. On the generalized cost-demand elasticity of intermodal container transport. European Journal of Transport and Infrastructure Research 14 (4): 362-374.

Kaack, L.H., P. Vaishnav, M.G. Morgan, I.L. Azevedo, and S. Rai. 2018. Decarbonizing intraregional freight systems with a focus on modal shift. Environmental Research Letters. https://doi.org/10. 1088/1748-9326/aad56c/meta.

Kelleher, G., A. El-Rhalibi, and F. Arshad. 2003. Scheduling for intermodal transport. Logistics Information Management 16 (5): 363-372.

Kemme, N. 2012. Effects of storage block layout and automated yard crane systems on the performance of seaport container terminals. OR Spectrum 34 (3): 563-591. https://doi.org/10.1007/ s00291-011-0242-7.

Kengpol, A., W. Meethom, and M. Tuominen. 2012. The development of a decision support system in multimodal transportation routing within Greater Mekong sub-region countries. International Journal of Production Economics 140 (2): 691-701. https://doi.org/10.1016/j.ijpe.2011.02.024.

Kolar, P., H.J. Schramm, and G. Prockl. 2018. Intermodal transport and repositioning of empty containers in Central and Eastern Europe hinterland. Journal of Transport Geography 69: 73-82. https://doi. org/10.1016/j.jtrangeo.2018.04.014.

Konings, R. 2007. Opportunities to improve container barge handling in the port of Rotterdam from a transport network perspective. Journal of Transport Geography 15 (6): 443-454. https://doi.org/10. 1016/j.jtrangeo.2007.01.009.

Konings, R., E. Kreutzberger, and V. Maras. 2013. Major considerations in developing a hub-and-spoke network to improve the cost performance of container barge transport in the hinterland: the case of the port of Rotterdam. Journal of Transport Geography 29: 63-73. https://doi.org/10.1016/j.jtran geo.2012.12.015. 
Konings, R., and V. Maras. 2011. Hub-and-spoke networks to increase the scope of container-on-barge transport performance analysis. Transportation Research Record. https://doi.org/10.3141/2222-12.

Konings, R., and H. Priemus. 2008. Terminals and the competitiveness of container barge transport. Transportation Research Record. https://doi.org/10.3141/2062-06.

Konings, R. 2006. Hub-and-spoke networks in container-on-barge transport. In Inland Waterways, Ports, and Shipping, 23-32.

Konings, R., M. van der Horst, N. Hutson, and J. Kruse. 2010. Comparative strategies for developing hinterland transport by container barge analysis for Rotterdam and US ports. Transportation Research Record. https://doi.org/10.3141/2166-10.

Kos, S., L. Vukic, and D. Brcic. 2017. Comparison of external costs in multimodal container transport chain. Promet-Traffic \& Transportation 29 (2): 243-252. https://doi.org/10.7307/ptt.v29i2.2183.

Kotowska, I., M. Mankowska, and M. Plucinski. 2018. Inland shipping to serve the hinterland: the challenge for seaport authorities. Sustainability 10 (10): 3468. https://doi.org/10.3390/su10103468.

Kumawat, G.L., D. Roy, R. De Koster, and I. Adan. 2021. Stochastic modeling of parallel process flows in intra-logistics systems: applications in container terminals and compact storage systems. European Journal of Operational Research 290 (1): 159-176. https://doi.org/10.1016/j.ejor.2020.08.006.

Larsen, R.B., B. Atasoy, and R.R. Negenborn. 2021. Model predictive control for simultaneous planning of container and vehicle routes. European Journal of Control 57: 273-283. https://doi.org/10. 1016/j.ejcon.2020.06.003.

Lee, B.K., L.H. Lee, and E.P. Chew. 2014a. Analysis on container port capacity: a Markovian modeling approach. OR Spectrum 36 (2): 425-454. https://doi.org/10.1007/s00291-012-0318-z.

Lee, E., P.G. Oduor, K. Farahmand, and D. Tolliver. 2014b. A coupled linear programming model with geospatial dynamic trip assignment for global-scale intermodal transportation. Maritime Economics \& Logistics 16 (1): 33-54. https://doi.org/10.1057/mel.2013.22.

Lee, L.H., E.P. Chew, K.C. Tan, and Y.B. Han. 2006. An optimization model for storage yard management in transshipment hubs. OR Spectrum 28 (4): 539-561. https://doi.org/10.1007/s00291-006-0045-4.

Lendjel, E., and M. Fischman. 2014. Innovations in barge transport for supplying French urban dense areas: a transaction costs approach. Supply Chain Forum 15 (4): 16-27. https://doi.org/10.1080/ 16258312.2014 .11517355 .

Li, M. 2016. Berth allocation with service limitations on vessels. HKIE Transactions 23 (2): 99-106.

Li, L., R.R. Negenborn, and B. De Schutter. 2014. Receding horizon approach for container flow assignment in intermodal freight transport. Transportation Research Record. https://doi.org/10.3141/ 2410-15.

Li, L., R.R. Negenborn, and B. De Schutter. 2015. Intermodal freight transport planning-a receding horizon control approach. Transportation Research Part C Emerging Technologies 60: 77-95. https://doi.org/10.1016/j.trc.2015.08.002.

Lin, C.C., Y.I. Chiang, and S.W. Lin. 2014. Efficient model and heuristic for the intermodal terminal location problem. Computers \& Operations Research 51: 41-51. https://doi.org/10.1016/j.cor. 2014.05.004.

Liu, X., Y. Bai, and J.H. Chen. 2017. An intermodal transportation geospatial network modeling for containerized soybean shipping. Journal of Ocean Engineering and Science 2 (2): 143-153. https:// doi.org/10.1016/j.joes.2017.05.001.

Lopez-Plata, I., C. Exposito-Izquierdo, B. Melian-Batista, and J.M. Moreno-Vega. 2018. Management of internal delivery vehicles in maritime container terminals. Progress in Artificial Intelligence 7 (1): 65-80. https://doi.org/10.1007/s13748-017-0129-1.

Lun, Y.H.V., K.H. Lai, and T.C.E. Cheng. 2013. An evaluation of green shipping networks to minimize external cost in the Pearl River Delta region. Technological Forecasting and Social Change. https:// doi.org/10.1016/j.techfore.2012.08.014.

Macharis, C., and Y.M. Bontekoning. 2004. Opportunities for OR in intermodal freight transport research: a review. European Journal of Operational Research 153 (2): 400-416. https://doi.org/ 10.1016/S0377-2217(03)00161-9.

Maione, G., A.M. Mangini, and M. Ottomanelli. 2016. A generalized stochastic Petri net approach for modeling activities of human operators in intermodal container terminals. IEEE Transactions on Automation Science and Engineering 13 (4): 1504-1516. https://doi.org/10.1109/TASE.2016. 2553439.

Maras, V. 2008. Determining optimal transport routes of inland waterway container ships. Transportation Research Record. https://doi.org/10.3141/2062-07. 
Maras, V., J. Lazic, T. Davidovic, and N. Mladenovic. 2013. Routing of barge container ships by mixedinteger programming heuristics. Applied Soft Computing 13 (8): 3515-3528. https://doi.org/10. 1016/j.asoc.2013.03.003.

Meers, D., T. Vermeiren, and C. Macharis. 2018. Transferia: solving local pain or bringing global gain? International Journal of Logistics Research and Applications 21 (2): 148-159.

Mishra, N., D. Roy, and J.K. van Ommeren. 2017. A stochastic model for interterminal container transportation. Transportation Science 51 (1): 67-87. https://doi.org/10.1287/trsc.2016.0726.

Monios, J., and G. Wilmsmeier. 2013. The role of intermodal transport in port regionalisation. Transport Policy 30: 161-172. https://doi.org/10.1016/j.tranpol.2013.09.010.

Musso, E., and A. Sciomachen. 2020. Impact of megaships on the performance of port container terminals. Maritime Economics \& Logistics 22 (3): 432-445. https://doi.org/10.1057/ s41278-019-00120-y.

Nasir, S., A. Muhammad, and H.S. Jaafar. 2019. Intermodal container movement in Malaysia: challenges and strategies to enhance its usage. Management Review: An International Journal 14 (1): 30-50.

Notteboom, T. 2007. Container river services and gateway ports: similarities between the Yangtze River and the Rhine River. Asia Pacific Viewpoint. https://doi.org/10.1111/j.1467-8373.2007.00351.x.

Notteboom, T., D. Yang, and H. Xu. 2020. Container barge network development in inland rivers: a comparison between the Yangtze River and the Rhine River. Transportation Research Part A Policy and Practice 132: 587-605. https://doi.org/10.1016/j.tra.2019.10.014.

Nur, F., M. Marufuzzaman, and S.M. Puryear. 2020. Optimizing inland waterway port management decisions considering water level fluctuations. Computers \& Industrial Engineering. https://doi.org/10. 1016/j.cie.2019.106210.

Paixao Casaca, A.C., and P.B. Marlow. 2005. The competitiveness of short sea shipping in multimodal logistics supply chains: service attributes. Maritime Policy \& Management 32 (4): 363-382.

Pant, R., K. Barker, F.H. Grant, and T.L. Landers. 2011. Interdependent impacts of inoperability at multimodal transportation container terminals. Transportation Research Part E Logistics and Transportation Review 47 (5): 722-737. https://doi.org/10.1016/j.tre.2011.02.009.

Park, N.K., B. Dragovic, and J.Y. Kim. 2009. Dynamic equipment deployment at a container terminal: transfer system based on real-time positioning. Strojniski Vestnik-Journal of Mechanical Engineering 55 (2): 83-94.

Radmilovic, Z., R. Zobenica, and V. Maras. 2011. River-sea shipping-competitiveness of various transport technologies. Journal of Transport Geography 19 (6): 1509-1516. https://doi.org/10.1016/j. jtrangeo.2011.03.002.

Radonjic, A., D. Pjevcevic, and V. Maras. 2020. Neural network ensemble approach to pushed convoys dispatching problems. Polish Maritime Research 27 (1): 70-82. https://doi.org/10.2478/ pomr-2020-0008.

Rajkovic, R., N. Zrnic, and D. Stakic. 2016. Application of a mathematical model for container transport flow of goods: from the Far East to Serbia. Tehnicki Vjesnik-Technical Gazette 23 (6): 1739-1746. https://doi.org/10.17559/TV-20140629203730.

Ramaekers, K., L. Verdonck, A. Caris, D. Meers, and C. Macharis. 2017. Allocating collaborative costs in multimodal barge networks for freight bundling. Journal of Transport Geography 65: 56-69. https://doi.org/10.1016/j.jtrangeo.2017.10.008.

Roso, V., N. Andersson, J. Widstrand, and K. Lumsden. 2015. Improvements in movement of empty containers: the case of the port of Gothenburg. Operations and Supply Chain Management-an International Journal 8 (1): 28-36.

Roukouni, A., H. Lukosch, A. Verbraeck, and R. Zuidwijk. 2020. Let the game begin: enhancing sustainable collaboration among actors in innovation ecosystems in a playful way. Sustainability 12 (20): 8494. https://doi.org/10.3390/su12208494.

Santos, T.A., and C. Soares. 2017. Development dynamics of the Portuguese range as a multi-port gateway system. Journal of Transport Geography 60: 178-188. https://doi.org/10.1016/j.jtrangeo.2017. 03.003.

Schepler, X., S. Balev, S. Michel, and E. Sanlaville. 2017. Global planning in a multi-terminal and multimodal maritime container port. Transportation Research Part E Logistics and Transportation Review 100: 38-62. https://doi.org/10.1016/j.tre.2016.12.002.

Scherbina, O., O. Drozhzhyn, O. Yatsenko, and O. Shybaev. 2019. Cooperation forms between participants of the inland waterways cargo delivery: a case study of the Dnieper region. Scientific Journal of Silesian University of Technology-Series Transport 103: 155-166. https://doi.org/10.20858/sjsut st.2019.103.12. 
Seo, Y.J., F.L. Chen, and S.Y. Roh. 2017. Multimodal transportation: the case of laptop from Chongqing in China to Rotterdam in Europe. Asian Journal of Shipping and Logistics 33 (3): 155-165. https:// doi.org/10.1016/j.ajs1.2017.09.005.

Shobayo, P., and E. van Hassel. 2019. Container barge congestion and handling in large seaports: a theoretical agent-based modeling approach. Journal of Shipping and Trade 4 (1): 1-26. https://doi.org/ 10.1186/s41072-019-0044-7.

Smid, M., S. Dekker, and B. Wiegmans. 2016. Modeling the cost sensitivity of intermodal inland waterway terminals: a scenario based approach. Transportation Research Part A Policy and Practice 85: 112-122. https://doi.org/10.1016/j.tra.2016.01.006.

Tan, Z.J., Q. Meng, F. Wang, and H.B. Kuang. 2018. Strategic integration of the inland port and shipping service for the ocean carrier. Transportation Research Part E Logistics and Transportation Review 110: 90-109. https://doi.org/10.1016/j.tre.2017.12.010.

Teye, C., M.G.H. Bell, and M.C.J. Bliemer. 2017. Urban intermodal terminals: the entropy maximising facility location problem. Transportation Research Part B Methodological 100: 64-81. https://doi. org/10.1016/j.trb.2017.01.014.

Ursavas, E., and S.X. Zhu. 2016. Optimal policies for the berth allocation problem under stochastic nature. European Journal of Operational Research 255 (2): 380-387. https://doi.org/10.1016/j. ejor.2016.04.029.

Van den Berg, R., and P.W. De Langen. 2015. Towards an 'inland terminal centred' value proposition. Maritime Policy \& Management 42 (5): 499-515. https://doi.org/10.1080/03088839.2014.928955.

van der Horst, M., M. Kort, B. Kuipers, and H. Geerlings. 2019. Coordination problems in container barging in the port of Rotterdam: an institutional analysis. Transportation Planning and Technology 42 (2): 187-199. https://doi.org/10.1080/03081060.2019.1565164.

van Riessen, B., R.R. Negenborn, and R. Dekker. 2016. Real-time container transport planning with decision trees based on offline obtained optimal solutions. Decision Support Systems 89: 1-16. https:// doi.org/10.1016/j.dss.2016.06.004.

Veenstra, A., R. Zuidwijk, and E. van Asperen. 2012. The extended gate concept for container terminals: expanding the notion of dry ports. Maritime Economics \& Logistics 14 (1): 14-32. https://doi.org/ $10.1057 / \mathrm{mel} .2011 .15$.

Vis, I.F.A., and R. de Koster. 2003. Transshipment of containers at a container terminal: an overview. European Journal of Operational Research 147 (1): 1-16. https://doi.org/10.1016/S0377-2217(02) 00293-X.

Wadhwa, S.S., K. Farahmand, and K. Vachal. 2019. A deterministic mathematical model to support future investment decisions for developing inland container terminals. Research in Transportation Economics. https://doi.org/10.1016/j.retrec.2019.100764.

Wagener, N. 2017. Intermodal logistics centres and freight corridors concepts and trends. Logforum 13 (3): 273-283. https://doi.org/10.17270/j.log.2017.3.3.

Wagener, N. 2014. Intermodal transport in Europe-opportunities through innovation. LogForum 10 (4): 371-382.

Wiegmans, B., and R. Konings. 2015. Intermodal inland waterway transport: modelling conditions influencing its cost competitiveness. Asian Journal of Shipping and Logistics 31 (2): 273-294.

Wiegmans, B., P. Witte, and T. Spit. 2015. Characteristics of European inland ports: a statistical analysis of inland waterway port development in Dutch municipalities. Transportation Research Part A Policy and Practice 78: 566-577. https://doi.org/10.1016/j.tra.2015.07.004.

Williamsson, J., S. Rogerson, and V. Santen. 2020. Business models for dedicated container freight on Swedish inland waterways. Research in Transportation Business and Management. https://doi.org/ 10.1016/j.rtbm.2020.100466.

Yahalom, S., C.Q. Guan, and E. Johansson. 2020. An innovative intermodal solution to urban residential waste disposal in large cities: a marine highway solution to a growing environmental problem. Maritime Economics \& Logistics. https://doi.org/10.1057/s41278-020-00164-5.

Yang, D., T. Notteboom, and X. Zhou. 2021. Spatial, temporal and institutional characteristics of entry strategies in inland container terminals: a comparison between Yangtze River and Rhine River. Journal of Transport Geography. https://doi.org/10.1016/j.jtrangeo.2020.102928.

Ypsilantis, P., and R. Zuidwijk. 2019. Collaborative fleet deployment and routing for sustainable transport. Sustainability 11 (20): 5666. https://doi.org/10.3390/su11205666.

Yu, H., Y.E. Ge, X.W. Fu, Y.F. Huang, Y.H. Zhang, and C.M. Tan. 2018. Capturing effects of container location dispersion on quay crane performance. Proceedings of the Institution of Civil EngineersMaritime Engineering 171 (1): 25-39. https://doi.org/10.1680/jmaen.2017.21. 
Zehendner, E., and D. Feillet. 2014. Benefits of a truck appointment system on the service quality of inland transport modes at a multimodal container terminal. European Journal of Operational Research 235 (2): 461-469. https://doi.org/10.1016/j.ejor.2013.07.005.

Zehendner, E., G. Rodriguez-Verjan, N. Absi, S. Dauzere-Peres, and D. Feillet. 2015. Optimized allocation of straddle carriers to reduce overall delays at multimodal container terminals. Flexible Services and Manufacturing Journal 27 (2-3): 300-330. https://doi.org/10.1007/s10696-013-9188-1.

Zhang, A., W.S. Zhang, Y. Chen, G.T. Chen, and X.F. Chen. 2017. Approximate the scheduling of quay cranes with non-crossing constraints. European Journal of Operational Research 258 (3): 820828. https://doi.org/10.1016/j.ejor.2016.10.021.

Zhang, H.T., C.Y. Lee, and T. Li. 2016. The value of specific cargo information for substitutable modes of inland transport. Transportation Research Part E Logistics and Transportation Review 85: 23-39. https://doi.org/10.1016/j.tre.2015.10.010.

Zhang, M., M. van den Driest, B. Wiegmans, and L. Tavasszy. 2014. The impact of $\mathrm{CO}_{2}$ pricing or biodiesel on container transport in and passing through the Netherlands. International Journal of Shipping and Transport Logistics 6 (5): 531-551. https://doi.org/10.1504/ijst1.2014.064575.

Zhang, R.Y., C. Huang, and X.H. Feng. 2020. Empty container repositioning with foldable containers in a river transport network considering the limitations of bridge heights. Transportation Research Part A Policy and Practice 133: 197-213. https://doi.org/10.1016/j.tra.2020.01.019.

Zhao, J.H., X.N. Zhu, Y. Liu, L. Wang, and B.C. Yan. 2018. A practical model for inbound container distribution organization in rail-water transhipping terminal. Journal of Control Science and Engineering. https://doi.org/10.1155/2018/9148405.

Zhen, L. 2014. Container yard template planning under uncertain maritime market. Transportation Research Part E Logistics and Transportation Review 69: 199-217. https://doi.org/10.1016/j.tre. 2014.06.011.

Zhen, L., K. Wang, S.A. Wang, and X.B. Qu. 2018. Tug scheduling for hinterland barge transport: a branch-and-price approach. European Journal of Operational Research 265 (1): 119-132. https:// doi.org/10.1016/j.ejor.2017.07.063.

Zhu, W.Y., H.W. Wang, and X.H. Zhang. 2021. Synergy evaluation model of container multimodal transport based on BP neural network. Neural Computing and Applications. https://doi.org/10.1007/ s00521-020-05584-1.

Zuidwijk, R.A., and A.W. Veenstra. 2015. The value of information in container transport. Transportation Science 49 (3): 675-685. https://doi.org/10.1287/trsc.2014.0518.

Zweers, B.G., S. Bhulai, and R.D. van der Mei. 2020. Planning hinterland container transportation in congested deep-sea terminals. Flexible Services and Manufacturing Journal. https://doi.org/10. 1007/s10696-020-09387-3.

Zweers, B.G., S. Bhulai, and R.D. van der Mei. 2019. Optimizing barge utilization in hinterland container transportation. Naval Research Logistics 66 (3): 253-271. https://doi.org/10.1002/nav.21837.

Publisher's Note Springer Nature remains neutral with regard to jurisdictional claims in published maps and institutional affiliations. 